\title{
A Collaborative Approach to a Chronic Care Problem
}

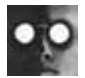

INVITED ESSAY

Jennifer Y. Verma, MSc, BJH

Senior Director, Canadian Foundation for Healthcare Improvement

Ottawa, ON

Jean-Louis Denis, $\mathrm{PHD}$

Professor, Canada Research Chair in Health Systems Governance and Transformation École nationale d'administration publique

Montréal, QC

Stephen Samis, MA

Vice-President, Canadian Foundation for Healthcare Improvement

Ottawa, ON

François Champagne, $\mathrm{PHD}$

Professor, Université de Montréal

Montréal, QC

Maureen O'Neil, oc

President, Canadian Foundation for Healthcare Improvement

Ottawa, ON

$\propto$

ABSTRACT

Quality improvement collaboratives (QICs) are popular vehicles for supporting healthcare improvement; however, the effectiveness of these models and the factors associated with their success are not fully understood. This paper presents a QIC in the Canadian context, where provincial healthcare systems have historically faced difficulty in transcending their structural and political limitations as well as moving 
from reactive models of care (prioritizing illness treatment in a hospital-reliant system) to more proactive ones (prioritizing population health in a primary care-based system). In March 2012, in a move that has been described as "unprecedented," 17 health regions across four provinces in Atlantic Canada, together with the Canadian Foundation for Healthcare Improvement (CFHI), developed a collaborative to improve chronic disease prevention and management. This paper introduces the Atlantic Healthcare Collaboration for Innovation and Improvement in Chronic Disease (AHC), reflecting on the experience of developing and implementing the model, which involved teams of front-line clinicians and managers working with CFHI faculty, coaches and staff to assess, design, implement, evaluate and share healthcare improvements for people living with chronic diseases. The paper shares key results and lessons learned from the AHC QIC experience, thus far, for improving chronic disease prevention and management in healthcare in Canada.

Every modern health system is in pursuit of moving from usual care to chronic disease prevention and management (CDPM). "Usual care" treats acute illness over brief periods and inadequately prevents disease or supports patients and providers in effectively managing chronic conditions and improving population health. In Canada, patients with complex health needs often report suboptimal care (Schoen et al. 2009; Schoen et al. 2011); more than half of adult Canadians live with at least one chronic condition and one-third live with two or more chronic conditions, with these figures rising as populations age (Public Health Agency of Canada [PHAC] 2013; Statistics Canada 2014). A number of sources show that a small proportion of people living with "high risk, high needs" (many of whom live with multiple chronic conditions) use the majority of healthcare resources (Kozyrskyj et al. 2005; Rais et al. 2013; Reid et al. 2003;
Wodchis et al. 2016) - services that are often hospital-based and, therefore, insufficient alone for patients with chronic and longerterm care needs. CDPM is distinguished from usual care by a focus on primary care, including prevention, with complete knowledge of the patient, clear accountability for the totality of care and involvement of specialists who improve care and increase primary care expertise (Wagner et al. 2014). A critical element of such an approach for patients living with chronic, long-term conditions is self-management, which extends beyond self-efficacy in daily activities to a greater personal role in preventative care and treatment (Panagioti et al. 2014; Taylor et al. 2014).

In Atlantic Canada, health system leaders worked with the CFHI - a not-for-profit, federally funded agency dedicated to accelerating healthcare improvement - to create a collaborative to improve the quality of care for people living with chronic disease. The AHC was forged in March 2012 to do the following (CFHI 2012a; 2012b):

- Create a patient- and family-centred approach to manage chronic diseases

- Build a network of organizational, regional and provincial teams to share evidenceinformed, systems-level solutions and work together to develop, implement and sustain improvement initiatives

- Promote sustainability of health systems

This paper presents the early experience of the AHC QIC, including its background and the lessons learned for improving CDPM and undertaking future QICs in Canada.

\section{Common Challenges Spur Collaboration}

Healthcare providers and organizations face persistent challenges in creating an integrated, patient-centred care approach, which is a 
requirement for the delivery of effective CDPM. In Atlantic Canada, the consequences of these challenges may be summarized as generally poorer health outcomes within a context of limited healthcare resources and competing health system priorities:

I. Escalating rates of chronic disease in aging populations. Compared to the rest of Canada, Atlantic Canada is home to higher rates of chronic disease (Canadian Institute for Health Information [CIHI] 2011; Statistics Canada 2013; 2014). Increased risk factors among all ages (such as poor nutrition, physical inactivity, obesity and smoking) and faster rates of population aging are escalating disease burden (Statistics Canada 2013). In 2008, more seniors in the Atlantic provinces reported living with one or more chronic conditions compared to the rest of Canada (76\%), ranging from $79 \%$ of seniors on Prince Edward Island (PEI) to $81 \%$ in each of Nova Scotia (NS) and New Brunswick (NB) to $85 \%$ in Newfoundland and Labrador (NL) (CIHI 2011).

2. Declining healthcare budgets at a time when care deficits persist. Historically, healthcare costs have grown faster in Atlantic Canada than in the rest of Canada (CIHI 2014). In recent years, Canadian provinces have taken steps to bend the cost curve through, for example, making lean improvements and reducing overall spending. While these measures can serve to contain costs in the short term, they often fall short of addressing persistent care deficits, such as uneven application of best practice guidelines, lack of care coordination and active patient follow-up, and inadequate self-management education for patients, families and providers (MacColl Center for Health Care
Innovation 2002). Shifting the emphasis of care to focus more on CDPM requires a systems approach. Taking such an approach is challenging in the Canadian healthcare context, as it is characterized by dispersed leadership, is largely acutebased and is in need of new care delivery models and services.

3. Competing priorities crowd out focus on patient-centred CDPM. A document analysis of key health-system priorities (based on the strategic plans from every health region and department of health in Atlantic Canada as of January 2012) revealed a predominant preoccupation with acute care (Akunov and Leith 2012). Quality of care issues such as safety, access and wait times within facility-based care topped the list of priorities. Atlantic health region CEOs, health department representatives and CFHI staff who came together to discuss the findings were surprised that CDPM featured less prominently in regional priorities (even though, as one healthcare CEO put it, "Atlantic Canada wins the prize for its high rates of mortality and morbidity due to chronic disease"). More striking was the particularly low profile attributed to patient engagement and patient- and family-centred care, which participants felt ought to inform any new improvement efforts.

CFHI and the Atlantic Regional Health Authorities (RHAs) seized the opportunity to initiate a pan-Atlantic Canada healthcare improvement collaboration, founding the AHC. Predating the collaborative, the CFHI EXTRA Executive Training Program had engaged healthcare leaders and teams across the country, including many in Atlantic Canada (CFHI 2015). In addition, CFHI had undertaken a successful CDPM 
collaborative in the Northwest Territories (CFHI 2013). Building on these improvement efforts, CFHI and all 17 RHAs from Atlantic Canada, with endorsement from the four provincial departments of health, formalized their commitment through a charter agreement, which determined the goals, activities and other features of the collaborative (CFHI 2012a). Governing the collaborative was an executive committee composed of Atlantic RHA and CFHI leadership. At its core, the AHC supported multidisciplinary teams of front-line clinicians and managers to assess, design, implement, evaluate and share healthcare improvements for people living with chronic diseases.

The last AHC workshop was in June 2014, with continued coaching support to the end of 2014, a follow-up webinar with teams in January 2015 and dissemination webinars to share team and collaborative learning in fall 2015. Outreach to teams soliciting further details on team improvement project (IP) progress continues, given the continued emphasis on evaluation of results and sharing key learning. What follows is a description of the AHC as well as the early learning from the individual teams and overall collaborative results.

\section{Collaborative Action for Better Chronic Care: The AHC Model}

QICs are popular vehicles for improving healthcare, with at least 20 years of application, but there is still scant evidence on their effectiveness (de Silva 2014; Nadeem et al. 2013). A recent literature review commissioned by the Health Foundation in the UK (Bibby 2014; de Silva 2014) explored the effectiveness of QICs, determining the following success factors for delivering high-impact collaboratives:

- Who: A collaborative is only as strong as the time, energy and willingness of the people involved to participate, which are improved when healthcare professionals and patients work together with senior management support.

- What: A key investment toward yielding down-the-road results is a well-articulated problem and solution. Without clarity in focus, efforts can dwindle, as teams lose motivation for what can easily turn into futile efforts toward unrealistic or vague goals.

- How: "Some is still not a number; soon is still not a time" (Gauthier 2014) is sage advice for collaboratives, in which success comes to those who work toward the same aims and within agreed-upon timelines. Following a "low-rules approach," where teams decide how best to make the required changes, is critical; however, they need a systematic combination of evidence-based practice and quality improvement (QI) approaches to design and implement their changes.

- With what resources: Sustaining momentum once the excitement of a collaborative begins separates those collaboratives that have dedicated resources over the long haul and those that do not. With appropriate release time of staff and adequate evaluative support to allow for reflective learning, teams can stay focused on their improvements rather than becoming burdened by administrative efforts to secure additional resources.

A 2013 Milbank Quarterly systematic literature review of the common components of QICs found collaboratives tend to focus on the following:

- Improving provider practices or patient outcomes (with the latter being more difficult to demonstrate over the generally short time frame of a QIC) 
- Structured activities for developmental team and cross-team learning

- Relying on expert guidance in evidencebased practice and QI within an improvement model that prioritizes measurable targets, data collection and feedback

- Multidisciplinary teams executing small tests of change (Nadeem et al. 2013)
The AHC QIC came to fruition before these literature reviews were available; however, a comparison shows complementarity with the models cited (see Table 1).

The content for workshops and other supports provided to teams through the AHC QIC (described in Table 1) were based on two improvement models: the CFHI

Table 1. Description of the Most Common Structural and Process-Oriented Components of Quality Improvement Collaboratives (QICs) (reported by Nadeem et al. 2013) as Compared to the AHC QIC Model

\begin{tabular}{|c|c|c|}
\hline Component & Description & Application to the AHC QIC \\
\hline $\begin{array}{l}\text { Overall QIC } \\
\text { Structure }\end{array}$ & $\begin{array}{l}\square 12 \text { months on average } \\
\square \text { In-person learning sessions } \\
\text { led by expert faculty for } \\
\text { multidisciplinary teams } \\
\square \text { Team-led quality IPs } \\
\square \text { All in-person learning sessions } \\
\text { and most phone meetings } \\
\text { involved multiple sites }\end{array}$ & $\begin{array}{l}\square 24 \text { months plus pre-work and follow-up } \\
\square \text { In-person learning sessions (workshops) led by expert faculty } \\
\text { for multidisciplinary teams } \\
\square \text { Team-led quality IPs } \\
\square \text { Workshops and webinars involved all teams/sites, } \\
\text { improvement coaches, academic mentors, faculty and } \\
\text { invited guests (e.g., policy and decision-makers/leaders } \\
\text { participated in all workshops) } \\
\text { Phone meetings generally reserved for individual teams } \\
\text { with CFHI and the team's coach and mentor; coaches/ } \\
\text { mentors additionally met monthly by phone to exchange } \\
\text { information about teams/sites }\end{array}$ \\
\hline $\begin{array}{l}\text { Multidisciplinary QI } \\
\text { Teams* }\end{array}$ & $\begin{array}{l}\text { Most involve such teams, } \\
\text { but with limited detail as to } \\
\text { team roles (e.g., direct care } \\
\text { providers or management-level } \\
\text { staff; representing different } \\
\text { roles within an organizational } \\
\text { hierarchy) }\end{array}$ & $\begin{array}{l}\text { Teams composed of two to six members who are either } \\
\text { direct care providers or middle managers, with an assigned } \\
\text { team lead or co-leads } \\
\text { H Each team assigned an academic mentor and improvement } \\
\text { coach to expand team expertise, with support of senior } \\
\text { leadership }\end{array}$ \\
\hline In-Person Sessions* & $\begin{array}{l}\square \text { Three sessions of two days } \\
\text { each, on average } \\
\square \text { Foster team planning } \\
\text { and cross-site sharing of } \\
\text { experiences (e.g., through } \\
\text { site presentations, breakout } \\
\text { sessions, storyboards) }\end{array}$ & $\begin{array}{l}\square \text { Four workshops of two days each, hosted in each of the } \\
\text { Atlantic provinces } \\
\square \text { Foster team learning and planning as well as cross-team } \\
\text { sharing of experiences through a variety of approaches } \\
\text { (e.g., team presentations, roundtable and plenary } \\
\text { discussions, impact stories, site visits, networking receptions) }\end{array}$ \\
\hline $\begin{array}{l}\text { Content of In-Person } \\
\text { Sessions }\end{array}$ & $\begin{array}{l}\square \text { Didactic training in a particular } \\
\text { care process or practice } \\
\text { (e.g., the Chronic Care } \\
\text { Model [CCM]), training in QI } \\
\text { techniques (e.g., Plan-Do- } \\
\text { Study-Act [PDSA] cycles) }\end{array}$ & $\begin{array}{l}\text { Didactic training in CCM best practices (e.g., self- } \\
\text { management support) and QI (e.g., problem-based } \\
\text { assessment, evidence-based design, change management } \\
\text { and implementation, evaluation and performance } \\
\text { improvement, patient engagement, provider engagement, } \\
\text { sustainability and spread, impact story development) }\end{array}$ \\
\hline $\begin{array}{l}\text { PDSA (Plan-Do- } \\
\text { Study-Act) Cycles* }\end{array}$ & $\begin{array}{l}\square \text { Most report using PDSAs but } \\
\text { offer little detail as to sites' } \\
\text { experiences during PDSA } \\
\text { cycles, how PDSAs were } \\
\text { integrated into improvement } \\
\text { efforts or how ongoing data } \\
\text { collection informed the } \\
\text { QI process }\end{array}$ & $\begin{array}{l}\text { Did not make use of PDSA cycles } \\
\text { H Employed a common approach to improvement (as per } \\
\text { the CFHI Improvement Approach: Assess, Design, } \\
\text { Implement, Evaluate [CFHI 2014b]) and posed validation } \\
\text { questions (e.g., Is your IP delivering what you thought it } \\
\text { would? If not, why not?) }\end{array}$ \\
\hline
\end{tabular}


Table 1. Description of the Most Common Structural and Process-Oriented Components of Quality Improvement Collaboratives (QICs) (reported by Nadeem et al. 2013) as Compared to the AHC QIC Model (continued)

\begin{tabular}{|c|c|c|}
\hline Component & Description & Application to the AHC QIC \\
\hline Team Calls & $\begin{array}{l}\square \text { Monthly team calls } \\
\square \text { Cross-site participation on calls }\end{array}$ & $\begin{array}{l}\square \text { Quarterly team calls } \\
\text { 冈 Team calls generally reserved for individual teams with CFHI } \\
\text { and the team's coach and mentor } \\
\text { H Webinars with cross-team participation } \\
\text { H Monthly coaching/mentorship calls, regular faculty calls and } \\
\text { quarterly executive committee calls involved exchanging } \\
\text { cross-team information }\end{array}$ \\
\hline $\begin{array}{l}\text { E-mail or Web } \\
\text { Support }\end{array}$ & $\begin{array}{l}\text { Web-based or e-mail support } \\
\text { sometimes offered but little } \\
\text { information as to the extent to } \\
\text { which QIC participants rely on } \\
\text { this support }\end{array}$ & $\begin{array}{l}\square \text { Customized, bilingual web-based learning platform (dubbed } \\
\text { "the Atlantic Desktop") for AHC teams, faculty, coaches } \\
\text { and mentors, as well as e-mail support }\end{array}$ \\
\hline QI Processes* & $\begin{array}{l}\square \text { Most incorporate ongoing data } \\
\text { collection (e.g., performance } \\
\text { indicators, ongoing reporting } \\
\text { on target outcomes) } \\
\text { In some cases, faculty provide } \\
\text { site feedback and receive } \\
\text { external support for data } \\
\text { synthesis and feedback }\end{array}$ & $\begin{array}{l}\text { Measurement and data collection plans gathered team/ } \\
\text { IP-specific indicators and reporting, with collaborative-level } \\
\text { metrics also incorporated } \\
\text { - IP indicator examples: effectiveness measures such } \\
\text { as knowledge and skills acquisition (provider), number } \\
\text { of referrals to a new service, implementation of } \\
\text { standardized order sets; patient- and family-centred care } \\
\text { measures such as client satisfaction, self-efficacy, patient } \\
\text { input to care processes } \\
\text { - Collaborative indicator examples: team attendance } \\
\text { in face-to-face and virtual learning activities; team } \\
\text { knowledge and skills acquisition; team satisfaction } \\
\text { (e.g., with workshop and webinar content, coaching); } \\
\text { growth of participant network } \\
\square \text { Faculty, coaches and mentors provided ongoing team/IP } \\
\text { feedback and CFHI evaluation staff provided support for } \\
\text { data synthesis and feedback }\end{array}$ \\
\hline $\begin{array}{l}\text { Organizational } \\
\text { Involvement }\end{array}$ & $\begin{array}{l}\square \text { Some report organizational } \\
\text { leadership involvement, } \\
\text { but not clear if leaders are } \\
\text { members of the QI team or } \\
\text { engaged via other means } \\
\square \text { Few examples of QIC } \\
\text { penetration into the broader } \\
\text { organization (e.g., training of } \\
\text { non-QIC team members by } \\
\text { either QIC faculty or local QIC } \\
\text { members) }\end{array}$ & $\begin{array}{l}\square \text { Organizational leadership involvement via the executive } \\
\text { committee, composed of senior-level leadership } \\
\square \text { Workshop materials/webinars available to broader } \\
\text { organizations, workshop invitations extended to select } \\
\text { non-QIC participants (e.g., from health departments and } \\
\text { across Canada) and CFHI supported/delivered customized } \\
\text { training by request (e.g., supporting several Atlantic-based } \\
\text { chronic care workshops/meetings) }\end{array}$ \\
\hline Pre-QIC Involvement & $\begin{array}{l}\square \text { Few examples of "pre-work" } \\
\text { activities (e.g., use of an } \\
\text { "expert panel," a group that } \\
\text { finds targets for improvement } \\
\text { and plans the collaborative, } \\
\text { such as requiring formal } \\
\text { commitments, application or } \\
\text { "readiness" criteria) }\end{array}$ & $\begin{array}{l}\square \text { Pre-work involved teams developing IP plans that met } \\
\text { readiness criteria; CFHI staff also worked closely with faculty } \\
\text { to develop curriculum (workshop content and worksheets) } \\
\text { throughout the collaborative }\end{array}$ \\
\hline
\end{tabular}

*Indicates most common QIC components (as per Nadeem et al. 2013); $\square$ Indicates alignment; $\mathbf{\Xi}$ Indicates divergence; $\mathscr{H}$ Indicates additional feature 
Improvement Approach (CFHI 2014a) as the QI model and the CCM (MacColl Center for Health Care Innovation 2002) as the evidence-based practice model. The CFHI Improvement Approach guided the overall improvement direction, with curriculum and coaching designed to develop team-based capacity to assess the underlying health system problem, design an evidence-informed solution, implement the change and evaluate the difference it makes. Assessment, design, implementation and evaluation are important leadership competencies and practices that help gauge implementation progress of an IP (see Table 2a for a summary of team improvement progress). The CFHI Improvement
Approach also includes "levers" that enable and accelerate healthcare improvement, for example, relying on evidence to inform decisions at every stage of the improvement process and engaging patients and families in care redesign (CFHI 2014a; 2014b). The CCM (which is now referred to by its originators as simply The Care Model) provided a framework for understanding the design elements of CDPM improvements. These elements include self-management support (SMS), delivery system design, decision support and clinical information systems as well as community resources and policies (see Table 2a for a summary of team IP foci and chronic care design elements).

\section{Table 2a. AHC Team Improvement Projects' Foci and Alignment With the Chronic Care Model and CFHI Improvement} Approach

\begin{tabular}{|c|c|c|c|c|c|c|c|}
\hline & & & & $\begin{array}{l}\text { Improve } \\
\text { (as per t }\end{array}$ & $\begin{array}{l}\text { ment Prc } \\
\text { e CFHI In }\end{array}$ & $\begin{array}{l}\text { zss } \\
\text { vement Appr }\end{array}$ & ach) \\
\hline & in & Improvement Project Foci & $\begin{array}{l}\text { Chronic Care Model } \\
\text { Focus/Design Elements }\end{array}$ & Assess & Design & Implement & Evaluate \\
\hline $\bar{\varpi}$ & Health PEI & $\begin{array}{l}\text { - Understand the underlying causes of } \\
\text { higher-than-usual reported ambulatory care } \\
\text { sensitive conditions (ACSC) } \\
\text { - Develop web-based tool for patient-provider } \\
\text { exchanges and follow-up for SMS } \\
\text { - Outreach for patients with chronic } \\
\text { obstructive pulmonary disease (COPD) }\end{array}$ & $\begin{array}{l}\text { - SMS } \\
\text { - Delivery system design } \\
\text { - Decision support } \\
\text { - Clinical information } \\
\text { systems } \\
\text { - Community resources } \\
\text { and policies }\end{array}$ & Y & Y & $\mathrm{N}$ & $\mathrm{N}$ \\
\hline & Health PEI & $\begin{array}{l}\text { - SMS training to all Health PEI clinicians } \\
\text { (starting with primary care providers, then } \\
\text { expanding to acute care providers) }\end{array}$ & $\begin{array}{l}\text { - SMS } \\
\text { - Decision support } \\
\text { - } \text { Delivery system design }\end{array}$ & Y & Y & Y & Y \\
\hline & $\begin{array}{l}\text { Horizon } \\
\text { Health } \\
\text { Network }\end{array}$ & $\begin{array}{l}\text { - Evaluate the PEER } 126 \text { (Peers Engaged } \\
\text { in Education and Recovery) program - } \\
\text { age-appropriate psychosocial rehabilitation } \\
\text { services (for youth aged } 16 \text { to } 29 \text { years) and } \\
\text { community-based programming designed to } \\
\text { help youth reach goals for emotional, social } \\
\text { and psychological well-being }\end{array}$ & $\begin{array}{l}\text { - SMS } \\
\text { - Delivery system design } \\
\text { - Community resources } \\
\text { and policies }\end{array}$ & Y & Y & Y & Y \\
\hline & $\begin{array}{l}\text { Réseau } \\
\text { de Santé } \\
\text { Vitalité }\end{array}$ & $\begin{array}{l}\text { - Primary healthcare needs assessments and } \\
\text { priority setting in four communities } \\
\text { - Community engagement and population- } \\
\text { based health }\end{array}$ & $\begin{array}{l}\text { - Community resources } \\
\text { and policies }\end{array}$ & $N A^{1}$ & $Y$ & Underway & $\mathrm{N}$ \\
\hline
\end{tabular}


Table 2a. AHC Team Improvement Projects' Foci and Alignment With the Chronic Care Model and CFHI Improvement Approach (continued)

\begin{tabular}{|c|c|c|c|c|c|c|c|}
\hline & & & & $\begin{array}{l}\text { Impro } \\
\text { (as per }\end{array}$ & $\begin{array}{l}\text { ment Pro } \\
\text { e CFHI Im }\end{array}$ & $\begin{array}{l}\text { ess } \\
\text { ovement Apprc }\end{array}$ & ach) \\
\hline & $\begin{array}{l}\text { Jvince*/ } \\
\text { am }\end{array}$ & Improvement Project Foci & $\begin{array}{l}\text { Chronic Care Model } \\
\text { Focus/Design Elements }\end{array}$ & Assess & Design & Implement & Evaluate \\
\hline$\Sigma$ & $\begin{array}{l}\text { Nova } \\
\text { Scotia } \\
\text { Health } \\
\text { Authority } \\
\text { (formerly } \\
\text { Capital } \\
\text { Health) }\end{array}$ & $\begin{array}{l}\text { - Modified value-stream mapping to identify } \\
\text { gaps in care (current state) from the patient's } \\
\text { perspective and develop process improvements } \\
\text { to address these gaps (future state) } \\
\text { - Service redesign across four chronic disease } \\
\text { services to streamline processes and improve } \\
\text { care coordination } \\
\text { - Development of the Chronic Disease } \\
\text { Prevention and Management (CDPM) } \\
\text { Corridor }{ }^{\odot} \text { and Toolkit }\end{array}$ & $\begin{array}{l}\text { - SMS } \\
\text { - Delivery system design } \\
\text { - Decision support } \\
\text { - Clinical information } \\
\text { systems } \\
\text { - Community resources } \\
\text { and supports }\end{array}$ & Y & Y & Underway & $N$ \\
\hline $\bar{z}$ & $\begin{array}{l}\text { Central } \\
\text { Health }\end{array}$ & $\begin{array}{l}\text { - Create standing orders and care maps } \\
\text { as well as educate providers on existing } \\
\text { respiratory care programs } \\
\text { - } \text { Redesign the asthma clinic at the local } \\
\text { health centre into an adult ambulatory } \\
\text { respiratory care centre and educate providers } \\
\text { on its programs } \\
\text { - Develop a COPD outreach program based } \\
\text { on the INSPIRED COPD Outreach Program }{ }^{\mathrm{TM}} \text {, } \\
\text { acquire appropriate resources and educate } \\
\text { providers on the benefits for patients }\end{array}$ & $\begin{array}{l}\text { - SMS } \\
\text { - Delivery system design } \\
\text { - Decision support } \\
\text { - Community resources } \\
\text { and policies }\end{array}$ & Y & Y & Y & Y \\
\hline & $\begin{array}{l}\text { Eastern } \\
\text { Health }\end{array}$ & $\begin{array}{l}\text { - Survey/assessment of patients' satisfaction } \\
\text { and perceptions of effectiveness of the } \\
\text { current diabetes education program for } \\
\text { patients with type } 2 \text { diabetes to inform } \\
\text { future practice }\end{array}$ & - SMS & Y & $\mathrm{N}$ & $N$ & $N$ \\
\hline & $\begin{array}{l}\text { Labrador- } \\
\text { Grenfell } \\
\text { Health }\end{array}$ & $\begin{array}{l}\text { - Increase understanding of local factors } \\
\text { related to suicide for youth in Inuit } \\
\text { communities } \\
\text { - } \text { Review programs in the circumpolar world } \\
\text { that have the greatest impact on improving } \\
\text { mental health resiliency and suicide } \\
\text { prevention } \\
\text { - Develop community-specific suicide } \\
\text { prevention and mental health promotion } \\
\text { programs }\end{array}$ & $\begin{array}{l}\text { - Delivery system design } \\
\text { - Community resources } \\
\text { and policies }\end{array}$ & $N A^{2}$ & & & \\
\hline & $\begin{array}{l}\text { Labrador- } \\
\text { Grenfell } \\
\text { Health }\end{array}$ & $\begin{array}{l}\text { - Redesign primary healthcare clinic visits } \\
\text { to include an interdisciplinary team of } \\
\text { healthcare providers and community elders, } \\
\text { with specific focus on improved diabetes care }\end{array}$ & $\begin{array}{l}\text { - Delivery system design } \\
\text { - Community resources } \\
\text { and policies }\end{array}$ & & & & \\
\hline & $\begin{array}{l}\text { Labrador- } \\
\text { Grenfell } \\
\text { Health }\end{array}$ & 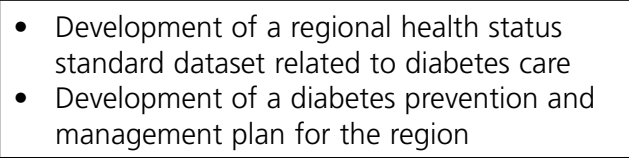 & $\begin{array}{l}\text { - Delivery system design } \\
\text { - Community resources } \\
\text { and policies }\end{array}$ & $\mathrm{Y}$ & Underway & $N A^{3}$ & \\
\hline & $\begin{array}{l}\text { Western } \\
\text { Health }\end{array}$ & $\begin{array}{l}\text { - Assess current diabetes provider/team } \\
\text { integration of SMS } \\
\text { - } \quad \text { Provide SMS training for providers } \\
\text { - Gather patient input into service design } \\
\text { through a patient survey and marketing of } \\
\text { compliments and complaints process } \\
\text { - Implement strategies to better recognize } \\
\text { and support emotional distress during } \\
\text { diabetes care }\end{array}$ & $\begin{array}{l}\text { - SMS } \\
\text { - Delivery system design } \\
\text { - Decision support }\end{array}$ & Y & Y & $\mathrm{Y}$ & Y \\
\hline
\end{tabular}


While the AHC QIC shares common features of existing QICs, it has several unique features:

- Shared governance and costing. An executive committee of Atlantic RHA CEOs and VPs governed the collaboration with CFHI leadership (CEO and VP of programs) and formalized their commitment in a charter that set the goals, activities and other features of the AHC (CFHI 2012a). The charter outlines a shared costing arrangement, formalizing all members' stake in the development, delivery and outcomes of the AHC. The arrangement entailed participating RHAs contributing to the costs associated with team workshop attendance and faculty-coaching stipends, as well as resources required to undertake local IPs. As per the terms of reference, the governance committee includes a rotating chair (currently the Health PEI CEO, who is one of the commentators on this issue) and CFHI staff (senior director and regional liaison), who serves as secretariat.

- Reliance on regional needs and expertise. Starting with an analysis of local strategic priorities, as defined by the Atlantic RHAs and provinces (Akunov and Leith 2012), the healthcare leaders who created the AHC QIC selected patient- and family-centred CDPM as the central focus. At its inception, the intention was to engage cross-regional and crossprovincial teams on shared IPs. However, this did not play out. CFHI worked with local leadership from each health region, who defined region-specific improvement aims, teams and IPs. Some would describe this process as a low-rules approach, as the executive committee relied on middle managers and healthcare providers to define the IPs based on their patient populations' needs, under the broad umbrella of CDPM. Also in accordance with a regional-based approach, the $\mathrm{AHC}$ hosted team workshops in each of the four Atlantic provinces, drew the majority of its coaching/mentorship capacity from the Atlantic region and incorporated a regional liaison (CFHI staff) position based in Moncton, NB, to serve as the key AHC point of contact. Given the need for bilingual (English-French) delivery, the collaborative was also delivered bilingually.

- Emphasis on connecting delivery to policy. Although provincial departments of health were neither formal signatories to the charter nor representatives on the executive committee (as per the committee's decision for the collaborative to be a delivery-level intervention and to be governed as such), the AHC paid special attention to fostering relationships with policy makers by creating opportunities for their participation in workshops (e.g., a health minister and other senior policy officials accepted invitations to welcome participants; and policy staff participated in the four workshops) and in discussions with the executive committee (e.g., policy makers helped to inform the charter as well as participated by invitation in several governance meetings). CFHI also responded to requests to prepare or deliver briefings and orientations to health departments on an ongoing and as-needed basis. These activities, while extensive, have not yet resulted in any policy changes nor influenced policy decisions; however, they served to create a channel whereby delivery-level improvements informed the policy context.

- Deployment of a support network for teams with coaching and mentorship. To assist teams in setting achievable goals, making measurable progress and realizing timely 
results, the AHC provided dedicated support from a number of people. In addition to the coordination and curriculum development offered by CFHI staff and faculty, the AHC provided each team with access to an academic mentor and improvement coach - external advisors who offered one-to-one feedback to teams over the course of the collaborative. Academic mentors were senior applied researchers and practitioners with an array of skills and expertise who assisted teams with problem formulation, methodology and data requirements, as well as the systematic assessment and application of evidence from research to improvement initiatives. Improvement coaches were experienced healthcare leaders or clinicians who assisted teams with the change management process and the tactical and strategic approaches necessary for effective IP implementation. Coaches and mentors were positioned to develop relationships with teams and thereby expand their expertise and local networks. The AHC QIC coaches and mentors brought a range of expertise from healthcare disciplines (such as nursing, medicine, psychology, pharmacy, allied health), policy and decision-making positions for example, former health region CEOs) as well as research backgrounds (including economics, governance, evaluation and decision support).

\section{Evaluating the AHC and Key Lessons Learned}

The AHC monitoring and evaluation plan was developed by CFHI staff and validated by faculty, coaches and mentors (Phillips et al. 2013). External advisors working with CFHI carried out the final evaluation, which relied on a variety of data sources (document analysis, post-workshop surveys, key inform- ant interviews, social networking analysis surveys and a focus group with CFHI staff [Champagne et al. 2015]). All of the findings in this section are drawn from the final evaluation, supplemented by observations arranged per each of the AHC QIC objectives: i) creating a patient- and family-centred approach to manage and prevent chronic disease; ii) building a network of organizational, regional and provincial teams to share evidence-informed, systems-level solutions and work together to develop, implement and sustain improvement initiatives; and iii) promoting sustainability of health systems.

\section{Create a patient- and family-centred approach to manage chronic diseases} Four teams (of the eight that fully participated in the AHC) implemented and evaluated their IPs over the course of the AHC (see Table $2 \mathrm{a}$ and Table $2 \mathrm{~b}$ ). Consistent with the aim of the collaborative - to create a patient- and family-centred approach to managing and preventing chronic disease these four teams implemented elements of the CCM related to SMS, delivery system design, decision support and community resources and partnerships (see Table 3). Apropos of SMS, in particular, the AHC findings reveal that developing this element of the CCM depends on a set of conditions and predispositions, including the following:

- Prioritizing patient involvement at the outset - for example, a team member reported, "By asking [patients], they identified a need and now we are developing programming for that. I never would have picked that [need] out."

- Focusing on greater provider awareness of the importance of self-management for example, a team member said, "Self-management support should be integrated in the current functioning of 
the healthcare system and into regular care; it should not be another silo initiative but an opportunity to build a common project between different services."

- Offering support for provider behaviour change through skills development - for example, a team member reported, "[In terms of the] differences in providers' perception of their role toward patients for some, it shifted from a role of changing patients' behaviour to a role of encouraging patients to change."

\section{Table 2b. Key Milestones of the Four AHC Teams That Were Successful in Implementing and Evaluating Their} Improvement Projects

\begin{tabular}{|c|c|}
\hline Team & nent Project Milestones \\
\hline $\begin{array}{l}\text { Health } \\
\text { PEI }\end{array}$ & $\begin{array}{l}\text { - } 105 \text { (of the } ~ 1,000 \text { over the next three years) targeted healthcare providers have completed or are in the process } \\
\text { of SMS training, with additional clinicians on a wait-list for upcoming training. Post-workshop surveys show the } \\
\text { following: } \\
\text { - High provider satisfaction with the training and content, citing the main strengths as the patient/family tools, } \\
\text { practical examples and opportunity to apply the training in practice } \\
\text { - Provider confidence in their SMS ability, indicating a greater likelihood to implement the SMS behaviour change } \\
\text { techniques in practice } \\
\text { - Ability for providers to cite at least two behaviour changes they will make in practice, with the most commonly } \\
\text { cited changes as follows: } \\
\text { 1. Ask more questions and do a better job of listening } \\
\text { 2. Assess patient readiness to change and be non-judgmental } \\
\text { 3. Set goals with patients and identify barriers to change } \\
\text { 4. Apply the tools (e.g., importance/confidence scale, decisional balance, traffic light to assess readiness) }\end{array}$ \\
\hline $\begin{array}{l}\text { Horizon } \\
\text { Health } \\
\text { Network }\end{array}$ & $\begin{array}{l}\text { - Surveys focusing on levels of concern in } 14 \text { life areas pre- and post-PEER } 126 \text { show youth self-report improvements } \\
\text { in all areas (including mental health, work, relationships and money) with the exception of spirituality. } \\
\text { - PEER } 126 \text { youth participants report reaching or making progress toward goals (e.g., the area of friendships and } \\
\text { activities shows the most significant progress, while participants report developing skills for future employment as } \\
\text { progress toward the area of active employment). } \\
\text { - Healthcare utilization data show PEER } 126 \text { youth participants experienced decreased use of emergency room visits, } \\
\text { community mobile mental health services and hospital admissions for a mental health diagnosis (compared to } \\
\text { pre-PEER 126). }\end{array}$ \\
\hline $\begin{array}{l}\text { Central } \\
\text { Health }\end{array}$ & $\begin{array}{l}\text { - The former asthma outpatient clinic was redesigned into the Respiratory Care Centre, which uses a nine-month } \\
\text { pathway combining on-site medical management with education and SMS and is filling a previously underserviced } \\
\text { need for the mild-moderate COPD population (having seen } 60 \text { patients in a two-month span since opening). } \\
\text { - A local version of the INSPIRED COPD Outreach Program }{ }^{\mathrm{TM}} \text { was created for patients living with advanced COPD } \\
\text { and their families - the program targets patients with COPD who have been hospitalized, to offer a program of } \\
\text { home-based support including self-management education, action plan development, psychosocial support and, } \\
\text { where appropriate, advance care planning. }\end{array}$ \\
\hline $\begin{array}{l}\text { Western } \\
\text { Health }\end{array}$ & $\begin{array}{l}\text { - } 100 \% \text { compliance reported based on an implementation audit of a depression-screening tool for people living } \\
\text { - Sith type } 2 \text { diabetes. } \\
\text { - Staff educated on a new "compliments and complaints policy" for soliciting patient feedback and patients } \\
\text { surveyed on existing program strengths, which include the following: } \\
\text { - Knowledgeable, skilled, respectful, courteous and helpful service providers } \\
\text { - Easily and conveniently scheduled appointments } \\
\text { - Helpful diabetes management plans, education sessions and appointments } \\
\text { - Patient-reported self-confidence in diabetes management, particularly vis-à-vis healthy eating, daily activities } \\
\text { - Team physician visits. } \\
\text { - Results from the Assessment of Primary Care Resources and Supports for Chronic Disease Self Management (PCRS) } \\
\text { conducted pre- and post- the aforementioned processes show improvements across all categories, for example: } \\
\text { - Emotional health - six out of seven teams met or exceeded the target of a } 2.0 \text { change, with a } 4.5 \text {-point } \\
\text { improvement from baseline to follow up } \\
\text { - Patient input - all teams met or exceeded the target of a } 2.0 \text { change, with a } 4.3 \text {-point improvement from } \\
\text { baseline to follow-up } \\
\text { - Physician, team and staff self-management education - six out of seven teams exceeded the target of a } 2.0 \\
\text { change, with a } 4.1 \text {-point improvement from baseline to follow-up; the 7th team reported a 1.0-point change. }\end{array}$ \\
\hline
\end{tabular}


Table 3. Key AHC Findings Associated With the Implementation of Patient- and Family-Centred Approaches to Chronic Disease Prevention and Management

\begin{tabular}{|c|c|c|}
\hline & & Key Findings \\
\hline $\begin{array}{l}\text { Health System } \\
\text { Elements of } \\
\text { the Chronic } \\
\text { Care Model }^{1}\end{array}$ & Self-management support & $\begin{array}{l}\text { - Patient involvement is a prerequisite for self-management. } \\
\text { - Provider awareness and buy-in regarding the need for and } \\
\text { - } \text { usefulness of self-management is needed. } \\
\text { - } \text { precursor for engaging patients in their own care. } \\
\text { - } \text { Mutual trust between providers and patients is essential. } \\
\text { - } \text { team-based support is important to promote self-management. } \\
\text { - Making tools available to patients and providers is crucial to } \\
\text { support the practice of self-management. }\end{array}$ \\
\hline & Delivery system design & $\begin{array}{l}\text { Patients provide highly valuable input in the co-design of care, } \\
\text { including unexpected insights as to how to organize and } \\
\text { deliver care. }\end{array}$ \\
\hline & Decision support & $\begin{array}{l}\text { - Adaptation of services to patient needs in real time is critical } \\
\text { to support responsive care systems. } \\
\text { - Proper follow-up and monitoring of patient attendance and } \\
\text { attrition rates to programming are important to better adapt } \\
\text { services. }\end{array}$ \\
\hline $\begin{array}{l}\text { Community } \\
\text { Element of the } \\
\text { Chronic Care } \\
\text { Model }\end{array}$ & $\begin{array}{l}\text { Community resources and } \\
\text { partnerships }\end{array}$ & $\begin{array}{l}\text { - Community collaboration is essential for increasing patient } \\
\text { engagement in behaviour changes. } \\
\text { - There are benefits to working with people from different } \\
\text { programs and with different experiences to help to better } \\
\text { integrate care. }\end{array}$ \\
\hline
\end{tabular}

1. There is no reference to the fourth health systems element - clinical information systems - as no key findings were realized as part of the AHC evaluation.

\section{Build a network to share solutions and work toward chronic care improvement}

The experience of health systems in their attempts to improve care suggests that these systems have an ongoing struggle with system inertia - the "tendency for a system to continue to do the same thing irrespective of changes in circumstances" (Coeira 2011: 27). The AHC aimed to provide a facilitative improvement environment. Findings from the AHC social networking analysis show that the collaborative afforded opportunities for participants to develop networks locally, cross-regionally and cross-provincially. From the baseline to the follow-up survey, increases are visible across all types of connections (in the categories of know, share and collaborate, which, as implied, assess the degree to which participants knew one another, shared information with one another or collaborated with one another; in analysis, the data was also examined across all categories, providing a fourth all category). Network density at least doubled across all types of connections, as did the number of ties (per capita) and the average degree (strength of the connection). The know network showed the greatest increase, with 132 new connections developed from baseline to follow-up; however, proportionally, the share network grew the most, with 2.67 times more connections over the same period. Importantly, while CFHI fostered the strongest connections at the outset, teams become more closely connected to the local expertise of faculty, coaches and mentors.

Networking was a positively reported component of the AHC QIC workshops as well. At the second workshop, 76\% of participants reported that opportunities for networking were either "very good" or "excellent"; 
at the third workshop, 84\% said the workshops helped them to identify opportunities for collaboration. Participant feedback helped to explain how the face-to-face networking helped. One participant said, "We are used to silos; [the workshop] was opening boundaries. It took us to this shared space. We learned a lot from other teams." Another reported, "We learned to link with people from other departments and other regional health authorities. My colleague doesn't work in the same department and so we are now working outside of silos." The workshops also afforded an opportunity to "not worry alone," as one informant put it, creating space to air shared concerns and work toward common goals.

A set of facilitating and limiting factors influenced the ability to create an environment for improvement (see Table 4). Support from leadership is important to align provincial or organizational policies with on-the-ground improvement efforts. Because providers develop routines in their day-to-day work, it appears valuable to have the support of external resources (e.g., CFHI as an improvement facilitator or academics and practitioners as mentors and coaches) to facilitate changing practices and models of care.
In addition, providers and organizations benefit from a customized and flexible approach to capacity development and timely intervention (e.g., from an independent thirdparty) to assist in a high-risk situation (e.g., when a team experiences turnover of its team lead). The participatory approach adopted by the AHC seems to favour the combination of various sources of experiential knowledge with research-informed evidence coming from various disciplines and research traditions. The potential benefits of this QIC are, however, constrained by the risk of providers and organizations becoming dependent on external support or distracted by the pressures of competing demands.

In terms of the lessons learned for undertaking and supporting QI more generally, the AHC experience (from all teams) provides lessons on implementation, development of QI competencies and facilitation of QI (through a QIC).

\section{Implementation}

The AHC results suggest that success in implementing CDPM improvements requires a set of conditions and predispositions. If attitudes and behaviours supportive

\section{Table 4. Key AHC Findings Associated With Building a Pan-Atlantic Canada Network to Share Solutions and Work Together Toward Chronic Care Improvement}

\begin{tabular}{|c|c|}
\hline $\begin{array}{l}\text { Influencing } \\
\text { Factors }\end{array}$ & Key Findings \\
\hline Facilitating & $\begin{array}{l}\text { - Collaboration supports from governing authorities in the system } \\
\text { - Alignment of IP with broader organizational strategic goals } \\
\text { - } \text { Initial and continual support from senior management } \\
\text { - } \text { Availability of and support from an external organization (CFHI), including at initial stage of } \\
\text { - CFHI model of governance: support to mediate conflicts, especially through communicating and } \\
\text { coordinating between team members; dedicated regional liaison based in the Atlantic region as } \\
\text { - } \text { a primary contact; strategic advice provided to teams } \\
\text { importance of integrating providers' and patients' perspectives in assessment of problems for } \\
\text { - Early integration of indicators and measurement in the development of the initiative }\end{array}$ \\
\hline Limiting & $\begin{array}{l}\text { - Lack of internal investment in continued improvement efforts (time and financial resources) } \\
\text { - Team members facing competing priorities and demands } \\
\text { - Low propensity to look for evidence, or lack of a culture of evaluation to support the design } \\
\text { of robust IPs }\end{array}$ \\
\hline
\end{tabular}


of chronic care already exist at an organization, for example, then teams may be better equipped to initiate and carry out chronic care improvements. As only half the teams followed through on implementation during the collaborative (see Table 2a), it is possible that these teams experienced more favourable conditions or were more equipped to address challenges that arose than the teams that did not implement (Parry et al. 2013). However, in one circumstance where a team did not initiate implementation, the environment was not the limiting factor; rather, the scale of the initiative required more time than the $\mathrm{AHC}$ QIC timeline allowed. Overall, the findings suggest that the implementation of chronic care improvements in real practice settings takes considerable time and effort, as has been demonstrated in studies examining success of QI efforts (Parry et al. 2013). Based on the AHC results, the key factors associated with implementation are:

- Continuity of and ongoing support from senior leadership to better care for people living with chronic diseases despite competing demands

- Continuity of staff (in terms of resource turnover)

- Dedicated time to develop new approaches to care delivery

- Multidisciplinary teams with clinical and QI (particularly evaluative) expertise

- Strong QI and evaluation culture in the host organization

- Ongoing communication with a common sense of mission and trust between providers and management

- Shared perceived vision regarding improvement of care for patients living with chronic disease, enabling the development of patient- and family-centred care

- Realistic objectives and timelines, with commitment to improvement
According to one key informant, "The most important learning [was] getting the leadership invited and committed at the beginning, so that teams are given the necessary support to do the work." While the collaborative focused at the level of delivery, some participants noted that the broader policy context matters, and that the collaborative would have benefited from more policy maker involvement. Participants also noted that patients "were not engaged enough" and ought to be "more present." CFHI encouraged teams to bring patients and families to the workshops and to actively engage them in their delivery-level efforts to redesign care. However, the limited engagement of patients and families overall indicates that this engagement needs to be built into the collaborative design process more deliberately.

These and other key implementation factors align well with the receptive context common to "high-performing health systems," which feature stability (low turnover) of leadership and staff; sound communication between managers and clinicians; investments (of time and resources) in improvement processes; and a strategic focus on, and a culture of, improvement, including high reliance on performance measurement and evaluation (Baker and Denis 2011; Baker et al. 2008).

\section{Competencies and skills}

In education and training, which are fundamental to the AHC QIC, it is well recognized that before results may be observed (e.g., did the organization improve its performance?), changes are likely to be seen in experience, learning and behaviour (Kirkpatrick and Kirkpatrick 2006). In terms of behaviour, Table 2a indicates whether teams were successful in assessment, design, implementation and evaluation. As for experience and learning, participants report gaining skills and competencies in the following areas: 
- Communication-Participants reported the need to consistently share and reinforce the aims and methods of their IPs within their host organizations, especially as team transitions and turnover occurred, and to maintain the "profile" of their IP as an organizational priority.

- Community engagement -Team members reported acquiring new knowledge regarding how to mobilize their local communities, whom to involve and how to collect data to inform design of new or existing services.

- Project management-Participants reported that the IP, in particular, was instructive in providing a practical, applied demonstration of how to manage a project (from design and planning through to execution and monitoring progress). The flexibility for IPs to be carried out through locally defined means also facilitated an understanding that a goal can be attained through different project management approaches, as long as there is a commitment to follow-through.

- Evaluation-While participants reported learning more about evaluation methods and practices (e.g., ways to standardize IP objectives, measurements and targets), many indicated that this led to a greater self-awareness that they or their organizations lacked skills or capacity to evaluate effectively. One participant reported, for example, "I learned a lot about evaluation to know that I didn't know much ... [and] you have to bring on the right people at the outset." Notably, those teams that were able to demonstrate results (as per Table 2b) had existing members with evaluative expertise or were able to recruit that expertise locally. While at least one other organization had this expertise, its project was large in scope and the scope was its limiting factor, not the lack of evaluative expertise.
- Implementation and spread - Postworkshop surveys show the majority of participants (89\%) agreed that workshop materials enhanced their understanding of developing a theory of change, how to design and implement an IP, how to redesign healthcare, ways to identify challenges, and opportunities for patient and provider engagement. Surveys also show that participants increased their skills related to sustainability and spread (97\%) and increased their understanding of methods for spreading best practices (85\%). A survey of coaches and mentors suggests that the AHC increased providers' confidence to engage in changes. "It provided the steps and support necessary for people, organizations and groups, with very little confidence in their ability, to implement" said one coach, while another reported, "There has been significant capacity-building at the individual and team level."

- Multidisciplinary teamwork - The practice of undertaking an IP as a team, in particular, provided an applied setting to develop awareness of multidisciplinary approaches and also challenged existing beliefs about what can be achieved through teamwork. For example, one participant reported learning that physicians are in fact open to changing practices, while another reported that teamwork served as a reminder that patient- and family-centred care should be part of the job.

\section{Facilitation of QI}

Participants reported positive experiences in regard to the components of this collaborative (described in Table 1). Among the factors supporting QICs are the following:

- Offering customized support/curriculum that respects the stage of progress of teams and their IPs 
- Providing additional (third-party) support in high-risk situations such as staff turnover

- Providing a coaching/mentorship model that combines complementary expertise (academic and practical, in this case)

- Promoting the fundamental principles of effective chronic care improvement across the health system (from delivery to policy)

- Understanding the need to better communicate IP progress and results with managers and colleagues on an ongoing basis

- Understanding team member competencies and areas of discomfort (e.g., data collection, evaluation, community partnership development, teamwork) so as to develop curriculum in line with need.

Participants considered the workshops, webinars and other curricula useful overall (the content of which is summarized in Table 1). "The educational programs were really quite good," reported one participant, who added, "The tools and processes to work through the issues were very helpful." Survey data collected throughout the collaborative corroborate this finding. For example, $74 \%$ of participants reported the four workshops were "very good" or "excellent" overall. After each workshop, participants rated specific elements. For example, at the fourth workshop, the following elements were rated as "very good" or "excellent": workshop content (85\%), workshop organization (88\%), guest faculty/presenters (88\%), pace of delivery (82\%) and participant involvement/engagement (85\%). The application of worksheets or tools received a notably lower score (70\%), though this lower ranking could be due to the teams' brief introduction to these worksheets and tools at the workshop followed by the expectation to complete and submit them post-workshop.

The "dual" coaching model - with teams supported by both an academic mentor and improvement coach - was highly regarded. Interviews with teams indicated that coaches/ mentors were invaluable, serving a variety of roles such as helping to keep IPs within scope and on deadline; facilitating connections to key stakeholders; and bringing forward new ideas, perspectives and resources. Coaches and mentors reported (by survey) that their roles could have been improved by involving them at the outset of the QIC. As context, CFHI worked with teams during and immediately following the first workshop to identify the kind of thematic expertise needed and only then invited coaches and mentors to participate. Even so, $80 \%$ of coaches/ mentors felt they succeeded in creating trust with their teams. In terms of role clarity, $78 \%$ of coaches/mentors reported that their role was clear; however, some reported ambiguity regarding how to handle sensitive matters, such as how to support a team during a tumultuous time (e.g., at a time of team member turnover or when IP workload is threatened by "scope creep").

In terms of the application of the customized, bilingual web-based learning platform (dubbed "the Atlantic Desktop"), survey findings show that it served more as a knowledge management platform (for document storage), with limited function otherwise. In fact, one coach remarked, "The web portal was useful to me as a coach but probably not [useful] to teams." Utilization data corroborate this finding, showing modest peaks in logins and page views pre- and post-workshops with little application otherwise.

Participants commented positively about the availability of CFHI staff; the bilingual delivery; and the responsive, iterative approach to curriculum design. "I can't think of a time when we asked for support and didn't receive it," said one participant - "[CFHI was] recognizing needs that we didn't know that we had and helping us along the way." Another partici- 
pant reported, "Everything was well planned - from the structure right through to the details and the organization. It appeared that everything [operated] like clockwork." Other important participant-reported characteristics of CFHI included its expertise and grasp of the healthcare landscape in Canada; its philosophy to "never leave the laggards behind," but to expend time and energy in supporting each team; its ability to recruit expert faculty, coaches and mentors; and its dedication to a regional approach, with a dedicated staff person in the region (the regional liaison).

\section{Promote sustainability of health systems}

When it comes to health system sustainability, it is only possible to make observations at this stage, given that most of the AHC IPs have not yet been implemented and others are at initial stages of implementation. We have even less to report on the matter of driving efficiencies and reducing per capita costs of care, though these are clearly crucial sustainability issues. Phillips and colleagues (2016) make further reference to this issue of "capturing cost" in the commentary paper that follows in the issue, in which they describe the measurement support to teams visà-vis capturing the cost of doing improvement as well as methods CFHI uses, where appropriate, to help teams understand the cost-benefit of new care delivery approaches. While many of the IPs in this collaborative aimed to deliver more efficient care (with aims explicitly related to efficiency or appropriateness of care, such as reducing waste and duplication in specialty care for patients with multiple chronic conditions, reducing inappropriate emergency department visits and hospitalizations through enhanced community-based care, and equipping providers and patients with SMSs to enable greater self-efficacy in CDPM), none tracked beforeand-after changes in unit costs, for example. In terms of sustainability of the IPs and teams' efforts to redesign care, because of the different evolution of the projects (including their not being at the same stage of implementation), it is challenging to assess sustainability. However, we offer several observations to this end:

- Team "improvement readiness assessments" can help set realistic expectations. It might help to yield greater team IP and collaborative success if more rigorous steps and problem-based analysis are undertaken at the outset of the collaborative (beyond what the AHC "readiness criteria" were able to achieve) to assess team and IP fit and QI capacity. This measure might also help with assessment of level of risk in regard to ability to follow through and dedicate the time necessary. Securing coaches and mentors from the outset of the collaborative to facilitate this kind of robust assessment may also be beneficial.

- Improving care takes dedicated time and commitment. Although this was a two-year collaborative - which the literature indicates is an above-average QIC lifespan (Nadeem et al. 2013) - the AHC QIC experience confirms that making sustainable change in the design, delivery and evaluation of care takes considerable time and commitment, often outliving the collaborative itself. CFHI will continue to follow up with teams to see how long improvement takes. Spreading IPs, meanwhile, has two dimensions - internal spread (within the walls of the host organization) and external spread (beyond its walls). No matter the scope, improvement is not static and requires continued efforts and support over time. Even once an initial improvement goal is reached, a new goal is likely to arise as improvement teams become more adept at recognizing and addressing problems. What matters is the dedicated commitment to a culture of improvement and the recognition of what 
it takes (in effort, time and resources) to achieve it.

- Local support matters. Teams that can align their IP efforts with local, organizational strategic priorities likely receive more reliable and ongoing support. This is important at the outset (e.g., carrying out IPs in conjunction with initiatives already underway to make use of existing resources and support), and once external resources or support ends (e.g., the ability of the team to continue its efforts once the collaborative's resources and improvement support end). Developing a regional community of practice may provide additional support to teams locally and contribute to their perseverance. The low-rules approach that informed the creation of team IPs was, arguably, an investment in local sustainability (internal spread) but not necessarily external spread. A low-rules approach leaves much open to local interpretation. On the one hand, such an approach allows for regional variation in, and customization of, the design of IPs responsive to local priorities and needs. On the other hand, this approach carries the inherent risk that regions undertake IPs that are widely different from one another, potentially limiting the degree to which cross-regional sharing may occur and contributing to the inability of teams to create cross-regional and cross-provincial IPs with the potential for higher system-wide impact.

\section{Where to From Here?}

Modernizing how healthcare addresses the needs of an increasingly chronically ill population is among the greatest challenges facing healthcare today. More people are living with multiple chronic conditions, putting pressure on healthcare systems that rely on facilitybased care to treat acute illness over brief periods of time. This paper provides an in-depth look at the AHC as a pan-Canadian $\mathrm{QIC}$ that developed a network of healthcare providers motived to initiate CDPM improvements for patients and families. In the end, what should we reasonably expect from this type of initiative? The AHC QIC created a predisposition to support better healthcare for patients and families living with chronic disease. This experience shows it is possible, in the context of healthcare in Canada, to stimulate a genuine commitment to improve care for patients with chronic disease and to address systematically some of the challenges and obstacles associated with healthcare improvement.

\section{Acknowledgements}

We would like to recognize our colleagues who co-designed and undertook the AHC evaluation: Kaye Phillips (senior lead), Claudia Amar (project lead), Pernelle Smits (consultant), Keesa Elicksen-Jensen, Tom Valente (consultant) and Nurdin Akunov. As well, we acknowledge those who made the AHC possible, with specific mentions to Meghan Rossiter (regional liaison), Erin Leith (coaching lead) and Christine (Kirby) Kirvan. In addition to receiving funding support from $\mathrm{CFHI}$, the AHC also received funding from five RHAs in Atlantic Canada: Nova Scotia Health Authority (formerly Capital Health, NS), Eastern Health (NL), Health PEI, Horizon Health Network and Réseau Santé Vitalité, (NB). Medavie Health Foundation also sponsored each of the four workshops, while Health Association Nova Scotia provided in-kind support. Most importantly, we would like to thank the tremendous network of executives, faculty, coaches and mentors, as well as the teams of dedicated healthcare professionals who participated. CFHI is funded through an agreement with Health Canada. The views expressed in this paper do not necessarily represent those of the Government of Canada. 


\section{References}

Akunov, N. and E. Leith. 2012. "An Analysis of Health System Priorities in Atlantic Canada: An Environmental Scan." Unpublished. Ottawa, ON: Canadian Foundation for Healthcare Improvement.

Baker, G.R. and J.L.D. Denis. 2011. A Comparative Study of Three Transformative Healthcare Systems: Lessons for Canada. Ottawa, ON: CFHI.

Baker, G.R., A. Macintosh-Murray, C. Pocellato, L. Dionne, K. Stelmacovich and K. Born. 2008. HighPerforming Healthcare Systems: Delivering Quality by Design. Toronto, ON: Longwoods.

Bibby, J. 2014. "Four Lessons for Running Impactful Collaboratives in Health Care." The Health Foundation. Retrieved January 15, 2015. <http://www. health.org.uk/blog/four-lessons-for-running-impactful-collaboratives-in-health-care/>.

Canadian Foundation for Healthcare Improvement (CFHI). 2012a. "Atlantic Healthcare Collaboration for Innovation and Improvement in Chronic Disease Charter." Retrieved January 15, 2015. <http://www. cfhi-fcass.ca/sf-docs/default-source/collaborations/ Atlantic-Charter-March12-2012-E.pdf>.

Canadian Foundation for Healthcare Improvement (CFHI). 2012b. "The Atlantic Healthcare Collaboration for Innovation and Improvement in Chronic Disease.” Retrieved January 15, 2015. <http://www.cfhi-fcass.ca/sf-docs/default-source/ collaborations/CFHI-Atlantic-Brochure-E.pdf $\rangle$.

Canadian Foundation for Healthcare Improvement (CFHI). 2013. "Making the Case for Change: Advancing the NWT Chronic Disease Management Strategy." Retrieved January 15, 2015. <http:// www.cfhi-fcass.ca/sf-docs/default-source/reports/ NWT-Report-E.pdf>.

Canadian Foundation for Healthcare Improvement (CFHI). 2014a. "CFHI Improvement Approach." Retrieved January 15, 2015. <http://www.cfhi-fcass. $\mathrm{ca} /$ AboutUs/OurApproach.aspx>.

Canadian Foundation for Healthcare Improvement (CFHI). 2014b. "Accelerating Healthcare Improvement: Canadian Foundation for Healthcare Improvement's Assessment Tool.” Retrieved January 15, 2015. <http://www.cfhi-cass.ca/ PublicationsAndResources/cfhi-self-assessment-tool>.

Canadian Foundation for Healthcare Improvement (CFHI). 2015. "EXTRA: Executive Training Program.” Retrieved January 15, 2015. <http://www. cfhi-cass.ca/WhatWeDo/extra>.

Canadian Institute for Health Information. 2011. "Seniors and the Health Care System: What Is the Impact of Multiple Chronic Conditions?" Retrieved
January 15, 2015. <https://secure.cihi.ca/free_products/air-chronic_disease_aib_en.pdf>.

Canadian Institute for Health Information (CFHI). 2014. "National Health Expenditure Trends, 1975 to 2014.” Retrieved January 15, 2015. <https://secure. cihi.ca/free_products/NHEXTrendsReport2014_ ENweb.pdf $>$.

Champagne, F., P. Smits, C. Amar, K. Elickson, J. Verma and K. Phillips. 2015. "Evaluation of the Atlantic Healthcare Collaboration." Ottawa, ON: CFHI.

Coeira, E. 2011. "Why System Inertia Makes Health Reform So Difficult." British Medical Journal 342: 3693. doi:10.1136/bmj.d3693

de Silva, D. 2014. "Improvement Collaboratives in Health Care." The Health Foundation. Retrieved January 15, 2015. <http://www.health.org.uk/publications/improvement-collaboratives-in-health-care>.

Gauthier, J. 2014, March 5. "Soon is still not a number, some is still not a time" [Web log post]. Institute for Healthcare Improvement. Retrieved January 15, 2015. <http:/www.ihi.org/communities/blogs/_layouts/ihi/ community/blog/itemview.aspx?List=7d1126ec-8f634a3b-9926-c44ea3036813\&ID=69> .

Kirkpatrick, D.L. and J.D. Kirkpatrick. 2006. Evaluating Training Programs (3rd. ed.). San Francisco, CA: Berrett-Koehler Publishers.

Kozyrskyj, A., L. Lix, M. Dahl and R.-A. Soodeen. 2005. "High-Cost Users of Pharmaceuticals: Who Are They?" Manitoba Centre for Health Policy, University of Manitoba. Retrieved January 15, 2015. <http://mchpappserv.cpe.umanitoba.ca/reference/high-cost.pdf $>$.

MacColl Center for Health Care Innovation, Group Health Research Institute. 2002. "The Care Model." Retrieved January 15, 2015. <http://www.improvingchroniccare.org/downloads/the_care_model_with_ copyright.jpg>.

Nadeem, E., S.S. Olin, L.C. Hill, K.E. Hoagwood and S.M. Horwitz. 2013. "Understanding the Components of Quality Improvement Collaboratives: A Systematic Literature Review." Milbank Quarterly 91(2): 354-94. doi:10.1111/milq.12016

Panagioti, M., G. Richardson, E. Murray, A. Rogers, A. Kennedy, S. Newman et al. 2014. "Reducing Care Utilisation Through Self-Management Interventions (RECURSIVE): A Systematic Review and MetaAnalysis." Health Services Delivery and Research 2(54).

Parry, G.J., A. Carson-Stevens, D.F. Luff, M.E. McPherson and D.A. Goldmann. 2013.

"Recommendations for Evaluation of Health Care Improvement Initiatives." Academic Pediatrics 13(6 Suppl): S23-S30. doi:10.1016/j.acap.2013.04.007 
Phillips, K., J. Verma, C. Amar, K. Elicksen and F. Champagne. 2013. "Atlantic Healthcare Collaboration: CFHI's Monitoring and Evaluation Plan." Available upon request.

Public Health Agency of Canada (PHAC). 2013. "Preventing Chronic Disease Strategic Plan 20132016." Retrieved January 15, 2015. < http://www. phac-aspc.gc.ca/cd-mc/diabetes-diabete/strategy_ plan-plan_strategique-eng.php >.

Rais, S., A. Nazerian, S. Ardal, Y. Chechulin, N. Bains and K. Maliko. 2013. "High-Cost Users of Ontario's Healthcare Services." Healthcare Policy 9(1): 44-51. doi:10.12927/hcpol.2013.23478

Reid, R., R. Evans, M. Barer, S. Sheps, K. Kerluke, K. McGrail et al. 2003. "Conspicuous Consumption: Characterizing High Users of Physician Services in One Canadian Province." Journal of Health Services Research and Policy 8(4): 215-24. doi:10.1258/135581903322403281

Schoen, C., R. Osborn, S.K. How, M.M. Doty and J. Peugh. 2009. "In Chronic Condition: Experiences of Patients With Complex Health Care Needs, in Eight Countries, 2008." Health Affairs 28(1): w1-16. doi:10.1377/hlthaff.28.1.w1

Schoen, C., R. Osborn, D. Squires, M. Doty, R. Pierson and S. Applebaum. 2011. "New 2011 Survey of Patients With Complex Care Needs in Eleven Countries Finds That Care is Often Poorly Coordinated." Health Affairs 30(12): 2437-48. doi:10.1377/hlthaff.2011.0923
Statistics Canada. 2013. "Health Profile, December 2013." Retrieved January 15, 2015. <http:// www12.statcan.gc.ca/health-sante/82-228/index. cfm?Lang $=\mathrm{E}>$.

Statistics Canada. 2014. "Canadian Socio-Economic Information Management System (CANSIM), Table 051-0001." Retrieved January 15, 2015. <http://www. statcan.gc.ca/tables-tableaux/sum-som/101/cst01/ demo31d-eng.htm>.

Taylor, S., H. Pinnock, E. Epiphanou, G. Pearce, H. Parke, A. Schwappach et al. 2014. "A Rapid Synthesis of the Evidence on Interventions Supporting Self-Management for People With Long-Term Conditions: PRISMS - Practical Systematic Review of Self-Management Support for Long-Term Conditions." Health Services and Delivery Research 2(53). doi.org/10.3310/hsdr02530

Wagner, E.H., N. Sandhu, K. Coleman, K.E. Phillips and J.R. Sugarman. 2014. "Improving Care Coordination in Primary Care." Medical Care 52(11 Suppl 4): S33-38. doi:10.1097/ MLR.0000000000000197

Wodchis, W., P.C. Austin and D.A. Henry. 2016. "A 3-Year Study of High-Cost Users of Health Care." Canadian Medical Association Journal doi: 10.1503/ cmaj.150064 


\title{
Une approche de collaboration à un problème de soins chroniques
}

\author{
- 0 \\ ESSAI INVITÉ \\ Jennifer Y. Verma, MSc, BJH
}

Directrice principale, Fondation canadienne pour l'amélioration des services de santé

Ottawa, ON

Jean-Louis Denis, $\mathrm{PHD}$

Professeur, titulaire de la Chaire de recherche du Canada sur la gouvernance et la transformation des organisations et systèmes de santé

École nationale d'administration publique

Montréal, QC

Stephen Samis, MA

Vice-président, Fondation canadienne pour l'amélioration des services de santé

Ottawa, ON

François Champagne, $\mathrm{PHD}$

Professeur, Université de Montréal

Montréal, QC

Maureen O'Neil, oc

Présidente, Fondation canadienne pour l'amélioration des services de santé

Ottawa, ON

RÉSUMÉ

Les projets collaboratifs d'amélioration de la qualité sont des outils populaires pour encourager l'amélioration des soins de santé; toutefois, l'efficacité de ces modèles et les facteurs associés à leur réussite ne sont pas pleinement compris. Cet article présente un projet collaboratif d'amélioration de la qualité dans un contexte canadien, où les systèmes de santé provinciaux ont souvent du mal à transcender leurs limites structurelles et politiques pour passer d'un modèle de soins réactif (priorisation du 
traitement de la maladie dans un système dépendant de l'hospitalisation) à une démarche plus proactive (priorisation de la santé de la population dans un système axé sur les soins primaires). En mars 2012, dans un geste qui a été qualifié de "sans précédent", 17 régions sanitaires des quatre provinces du Canada atlantique, de concert avec la Fondation canadienne pour l'amélioration des services de santé (FCASS), ont mis sur pied un collectif visant à améliorer la prévention et la gestion des maladies chroniques. Ce document présente la Collaboration des organismes de santé de l'Atlantique en matière d'innovation et l'amélioration dans le traitement des maladies chroniques (COSA), ainsi qu'une réflexion sur l'expérience de l'élaboration et de la mise en cuvre de ce modèle, qui réunissait des équipes de cliniciens de première ligne et des gestionnaires travaillant avec des enseignants, des formateurs et des membres du personnel de la FCASS à l'évaluation, à la conception, à la mise en cuvre, à l'évaluation et au partage d'améliorations des soins de santé pour les personnes atteintes de maladies chroniques. Ce document révèle les principaux résultats et enseignements tirés jusqu'à présent dans le cadre de ce projet collaboratif d'amélioration de la qualité (la COSA) dont l'objectif était d'améliorer la prévention et la gestion des maladies chroniques au Canada.

TouT sYsTÈme DE santé moderne s'efforce de passer des soins habituels à la prévention et à la gestion des maladies chroniques (PGMC). Les « soins habituels » traitent la maladie aiguë pendant de courtes périodes, mais ils ne parviennent pas suffisamment à prévenir la maladie ou à aider les patients et les prestataires à efficacement gérer les maladies chroniques ou à améliorer la santé de la population. Au Canada, les patients aux besoins thérapeutiques complexes déclarent souvent recevoir des soins moins qu'optimaux (Schoen et al. 2009 ; Schoen et al. 2011), bien que plus de la moitié des Canadiens adultes aient au moins un problème de santé chronique et que le tiers d'entre eux soit atteint de deux affections chroniques ou plus ; et que ces chiffres augmentent progressivement en raison du vieillissement de la population (Agence de santé publique du Canada [ASPC] 2013 ; Statistique Canada 2014). Un certain nombre de sources révèlent qu'une faible proportion de personnes ayant « des risques élevés et des besoins importants » (dont un bon nombre est atteint de maladies chroniques multiples) consomme la majorité des ressources de santé (Kozyrskyj et al. 2005 ; Rais et al. 2013 ; Reid et al. 2003 ; Wodchis et al. 2016). Ces services sont souvent de nature hospitalière et, par conséquent, insuffisants à eux seuls pour répondre aux besoins des patients atteints de maladies chroniques sur le long terme. La PGMC se distingue des soins habituels par l'attention qu'elle consacre aux soins primaires, notamment à la prévention, à la connaissance intégrale du patient, à la responsabilisation claire pour la totalité des soins et à la participation de spécialistes qui contribuent à améliorer les soins et à renforcer l'expertise des soins primaires (Wagner et al. 2014). Un élément essentiel d'une approche particulière aux patients atteints de maladies chroniques (ou à long terme), concerne l'autogestion, qui transcende l'auto-efficacité relative aux activités quotidiennes pour accorder un plus grand rôle au patient dans ses soins préventifs et son traitement (Panagioti et al. 2014 ; Taylor et al. 2014).

Dans les provinces atlantiques du Canada, des dirigeants du système de santé ont travaillé avec la FCASS (un organisme sans but lucratif financé par le gouvernement fédéral qui se consacre à l'accélération des améliorations en santé) afin de créer un collectif visant à améliorer la qualité des soins pour les personnes atteintes d'une maladie chronique. La Collaboration des organismes de santé de l'Atlantique (COSA) a été forgée en mars 2012 afin de réaliser ce qui suit (FCASS 2012a ; 2012b) : 
- Créer une approche centrée sur le patient et sa famille en matière de gestion des maladies chroniques ;

- Établir un réseau d'équipes organisationnelles, régionales et provinciales en vue de partager des données probantes sur d'éventuelles solutions systémiques et travailler ensemble à l'élaboration, à la mise en œuvre et à la pérennisation d'initiatives d'amélioration;

- Promouvoir la pérennité des systèmes de santé.

Cet article présente un recensement des premières expériences du projet collaboratif d'amélioration de la qualité COSA, dont sa genèse et ses enseignements dans le but d'améliorer la PGMC et la réalisation de futurs projets collaboratifs d'amélioration de la qualité au Canada.

\section{Les défis communs stimulent la collaboration}

Les prestataires de soins de santé et les organisations sont confrontés à des problèmes persistants tandis qu'ils s'efforcent de créer une approche intégrée de soins centrés sur le patient ; une exigence indispensable à la prestation efficace de la PGMC. Dans le Canada atlantique, les conséquences de ces problèmes se résument généralement à de moins bons résultats en matière de santé dans un contexte caractérisé par des ressources de santé limitées et la concurrence des priorités du système :

\section{Le taux croissant de maladies chroniques} dans les populations vieillissantes.

Comparativement au reste du Canada, le Canada atlantique est aux prises avec un taux plus élevé de maladies chroniques (Institut canadien d'information sur la santé [ICIS] 2011 ; Statistique Canada $2013 ; 2014$ ). Des facteurs de risque accrus chez les personnes de tous âges (comme la mauvaise alimentation, la sédentarité, l'obésité et le tabagisme) et le vieillissement accéléré de la population alourdissent le fardeau de la maladie (Statistique Canada 2013). En 2008, un plus grand nombre de personnes âgées vivant dans les provinces de l'Atlantique ont déclaré être atteintes d'une ou de plusieurs affections chroniques par rapport au reste du Canada (76\%), passant de 79 \% chez les aînés de l'Île-duPrince-Édouard (Î.-P.-É.) à $81 \%$ chez ceux de la Nouvelle-Écosse (N.-É.) et du Nouveau-Brunswick ((N.-B.) et même $85 \%$ à Terre-Neuve-et-Labrador (T.-N.-L.) (ICIS 2011).

2. Une diminution constante des budgets de santé à l'heure où les déficits de soins persistent. Dans le passé, le coût des soins de santé augmentait plus rapidement dans les provinces de l'Atlantique que dans le reste du Canada (ICIS 2014). Au cours des dernières années, les provinces canadiennes ont pris des mesures pour infléchir la courbe des coûts grâce, notamment, à des améliorations de la productivité et à une réduction générale des dépenses. Ces mesures peuvent certes servir à contenir les coûts à court terme, mais elles s'avèrent souvent insuffisantes pour régler le problème des déficits de soins persistants, tels que l'application inégale de lignes directrices sur les pratiques exemplaires, une coordination de soins et un suivi du patient lacunaires, et une sensibilisation imparfaite à l'autogestion chez les patients, les familles et les prestataires (MacColl Centre for Health Care Innovation 2002). Déplacer l'accent des soins vers la PGMC exige une approche systémique. L'adoption d'une telle approche constitue un défi de taille dans le contexte des soins de santé du Canada, qui sont caractérisés par un 
leadership diffus, une monomanie en faveur des soins actifs et un besoin urgent de nouveaux modèles de prestation de soins et de services.

3. Les priorités concurrentes étouffent la centralité du patient dans la prévention et la gestion des maladies chroniques. Une analyse documentaire des principales priorités du système de santé (fondée sur les plans stratégiques de toutes les régions sanitaires et de tous les ministères de la santé du Canada atlantique en date de janvier 2012) a révélé une préoccupation prédominante pour les soins actifs (Akunov et Leith 2012). Les questions touchant la qualité des soins comme la sécurité, l'accès et les temps d'attente en milieu hospitalier étaient en tête de liste des priorités. Les premiers dirigeants des régions sanitaires de l'Atlantique, les représentants des ministères de la santé et le personnel de la FCASS, réunis pour discuter de ces résultats, se sont étonnés que la PGMC occupe une place moins importante parmi les priorités régionales (malgré que, comme un PDG l'exprimait, « Le Canada atlantique remporte la palme en termes de taux de mortalité et de morbidité associés aux maladies chroniques »). Le plus frappant était sans doute la faible importance accordée à la participation du patient et de sa famille aux soins, qui, de l'avis des participants, devrait éclairer toute nouvelle initiative d'amélioration.

La FCASS et les autorités sanitaires régionales (ASR) de l'Atlantique ont saisi l'occasion de forger un collectif d'amélioration de la qualité pan-Canada atlantique en créant la COSA. Même avant la création de la Collaboration, le programme de formation pour cadres FORCES de la FCASS avait mobilisé des dirigeants et des équipes de soins de santé de partout au pays, dont un grand nombre dans le Canada atlantique (FCASS 2015). En outre, la FCASS avait entrepris une collaboration fructueuse sur la PGMC dans les Territoires du Nord-Ouest (FCASS 2013). En misant sur ces efforts d'amélioration, la FCASS et 17 ASR du Canada atlantique, avec l'aval des quatre ministères provinciaux de la santé, ont officialisé leur engagement au moyen d'une charte qui établissait les objectifs, les activités et d'autres caractéristiques de la Collaboration (FCASS 2012a). Un comité exécutif composé de dirigeants des ASR de l'Atlantique et de la FCASS dirigeait la Collaboration. À la base, la COSA appuyait des équipes multidisciplinaires de cliniciens de première ligne et des gestionnaires dans l'évaluation, la conception, la mise en œuvre, l'évaluation et le partage des améliorations de soins de santé pour les personnes atteintes de maladies chroniques.

Le dernier atelier de la COSA s'est tenu en juin 2014, bien que l'accompagnement des équipes se soit étendu jusqu'à la fin de 2014, qu'un webinaire de suivi avec les équipes ait été organisé en janvier 2015 et que des webinaires visant à diffuser les apprentissages des équipes et de la Collaboration aient été tenus à l'automne 2015. La communication avec les équipes pour obtenir plus de renseignements au sujet de l'évolution de leur projet d'amélioration (PA) se poursuit, compte tenu de l'importance de l'évaluation des résultats et du partage des apprentissages clés. Ce qui suit est une description de la COSA, des apprentissages préliminaires des diverses équipes et des résultats généraux de la Collaboration.

\section{Action concertée pour de meilleurs soins chroniques : le modèle de la COSA}

Les projets collaboratifs d'amélioration de la qualité sont des vecteurs populaires pour l'amélioration des soins de santé, grâce à leur historique de plus de 20 ans, bien qu'il existe 
encore peu de données probantes sur leur efficacité (de Silva 2014 ; Nadeem et al. 2013). Un examen de la littérature scientifique récemment commandé par la Health Foundation du Royaume-Uni (Bibby 2014 ; de Silva 2014) explorait l'efficacité de ces projets collaboratifs et recensait les facteurs de réussite suivants chez les collectifs à fort impact :

- Qui? Une collaboration ne sera jamais égale qu'au temps, à l'énergie et à la volonté des personnes concernées d'y prendre part ; qui bénéficient tous du travail concerté des professionnels de la santé et des patients, appuyé par des cadres dirigeants.

- Quoi ? Un problème et une solution bien articulés constituent un investissement important en vue de produire des résultats à terme. En l'absence d'une orientation bien définie, l'enthousiasme peut s'affaiblir, tandis que la motivation des équipes s'essouffle devant des objectifs inatteignables ou imprécis pour lesquels les efforts deviennent rapidement futiles.

- Comment? «Certains n'est toujours pas un nombre définitif ; pas plus que bientôt est un moment précis" (Gauthier 2014). Voilà un sage conseil pour les projets collaboratifs, car la réussite vient à ceux qui travaillent à atteindre des objectifs communs dans des délais convenus. L'observation d'une « approche faible en règles ", dans le cadre de laquelle les équipes sont libres de décider de la meilleure façon d'apporter les changements nécessaires, est fondamentale ; toutefois, une combinaison systématique d'approches fondées sur des données probantes et axées sur l'amélioration de la qualité (AQ) est indispensable à la conception et à la mise en œuvre des changements.

- Avec quelles ressources? Le maintien de l'élan, une fois passé l'enthousiasme initial d'un nouveau projet collaboratif, distingue les collectifs qui ont envisagé les ressources à long terme de ceux qui ne l'ont pas fait. Si le personnel dispose du temps voulu et du soutien nécessaire à l'évaluation, dans le but de réaliser un apprentissage réflexif, les équipes peuvent rester concentrées sur leurs améliorations plutôt que d'être accablées par des questions administratives visant à obtenir des ressources supplémentaires.

Un examen systématique de la littérature scientifique réalisé par Milbank Quarterly (2013) au sujet des traits communs des projets collaboratifs d'amélioration de la qualité a révélé que leurs efforts tendent à se concentrer sur les éléments suivants :

- L'amélioration des pratiques des prestataires ou des résultats pour le patient (ceux-ci étant plus difficiles à démontrer au cours de la durée généralement brève d'un projet collaboratif) ;

- Des activités structurées pour encourager l'apprentissage et le développement croisés des équipes ;

- Le recours à des conseils d'expert en matière de pratique fondée sur des données probantes et d'AQ dans le cadre d'un modèle d'amélioration qui priorise des cibles mesurables, la collecte de données et la rétroaction ;

- Des équipes multidisciplinaires qui réalisent de petits essais de changement (Nadeem et al. 2013).

Le projet collaboratif d'amélioration de la qualité COSA s'est concrétisé avant que ces études documentaires ne soient disponibles; cependant, une comparaison révèle une bonne complémentarité entre les modèles cités (voir le Tableau 1).

Le contenu des ateliers et d'autres formes de soutien fourni aux équipes dans le cadre du 
Tableau 1. Description des composants structurels et axés sur les processus les plus courants des projets collaboratifs d'amélioration de la qualité (selon Nadeem et al. 2013) par rapport au modèle du projet collaboratif d'AQ COSA

\begin{tabular}{|c|c|c|}
\hline Composant & Description & Application au projet collaboratif d'AQ COSA \\
\hline $\begin{array}{l}\text { Structure } \\
\text { générale } \\
\text { du projet } \\
\text { collaboratif d'AQ }\end{array}$ & $\begin{array}{l}\square 12 \text { mois en moyenne } \\
\square \text { Séances d'apprentissage } \\
\text { menées par des enseignants } \\
\text { experts à l'intention d'équipes } \\
\text { multidisciplinaires } \\
\square \text { Projets d'AQ dirigés par les équipes } \\
\square \text { Toutes les séances d'apprentissage } \\
\text { en personne, ainsi que la majorité } \\
\text { des téléconférences, réunissent } \\
\text { plusieurs établissements }\end{array}$ & $\begin{array}{l}\square 24 \text { mois en plus du travail préalable et de suivi } \\
\square \text { Séances d'apprentissage en personne (ateliers) menées par } \\
\text { des enseignants experts pour les équipes multidisciplinaires } \\
\square \text { Projets d'AQ dirigés par les équipes } \\
\square \text { Ateliers et webinaires réunissant toutes les équipes / tous } \\
\text { les établissements, formateurs en amélioration, mentors } \\
\text { universitaires, enseignants et invités (p. ex., des décideurs et } \\
\text { des responsables des politiques / dirigeants ont participé à } \\
\text { tous les ateliers) } \\
\text { 冈 En général, les téléconférences étaient réservées aux } \\
\text { équipes individuelles qui rencontraient le personnel de la } \\
\text { FCASS, leur formateur ou leur mentor ; les formateurs / } \\
\text { mentors se réunissaient tous les mois au téléphone pour } \\
\text { échanger de l'information sur les équipes / établissements }\end{array}$ \\
\hline $\begin{array}{l}\text { Équipes multi- } \\
\text { disciplinaires } \\
\text { d'AQ* }^{*}\end{array}$ & $\begin{array}{l}\text { La plupart réunissent de telles } \\
\text { équipes, mais avec peu de détails } \\
\text { sur les rôles de l'équipe } \\
\text { (p. ex., les prestataires de soins } \\
\text { directs ou le personnel de direction } \\
\text { qui représentent divers rôles de la } \\
\text { hiérarchie organisationnelle) }\end{array}$ & $\begin{array}{l}\text { V Équipes composées de deux à six membres qui sont } \\
\text { prestataires de soins directs ou cadres intermédiaires, dont } \\
\text { un ou deux chefs d'équipe } \\
\text { H Un mentor universitaire et un formateur en amélioration ont } \\
\text { été affectés à chaque équipe afin d'élargir son expertise, } \\
\text { avec l'appui de la haute direction de l'organisme }\end{array}$ \\
\hline $\begin{array}{l}\text { Séances en } \\
\text { personne* }\end{array}$ & $\begin{array}{l}\text { Trois séances de deux jours } \\
\text { chacune, en moyenne } \\
\square \text { Pour favoriser la planification de } \\
\text { l'équipe le partage d'expériences } \\
\text { entre établissements (p. ex., au } \\
\text { moyen d'exposés d'équipe, de } \\
\text { séances en petits groupes et de } \\
\text { scénarimages) }\end{array}$ & $\begin{array}{l}\square \text { Quatre ateliers de deux jours chacun dans chacune des } \\
\text { provinces de l'Atlantique } \\
\square \text { Pour favoriser l'apprentissage en équipe et la planification } \\
\text { ainsi que le partage des expériences acquises au moyen } \\
\text { d'approches diverses (p. ex., exposés d'équipe, tables } \\
\text { rondes, discussions en séance plénière, histoires à succès, } \\
\text { visites de sites et réceptions de réseautage) }\end{array}$ \\
\hline $\begin{array}{l}\text { Contenu des } \\
\text { séances en } \\
\text { personne }\end{array}$ & $\begin{array}{l}\text { Formation didactique dans le cadre } \\
\text { d'un processus ou d'une pratique } \\
\text { de soins en particulier (p. ex., } \\
\text { le Modèle de soins chroniques), } \\
\text { formation sur les techniques d'AQ } \\
\text { (p. ex., les cycles Planifier-Exécuter- } \\
\text { Étudier-Agir [PEEA]) }\end{array}$ & $\begin{array}{l}\text { Formation didactique en meilleures pratiques selon le } \\
\text { Modèle de soins chroniques (p. ex., soutien à l'autogestion) } \\
\text { et en } \mathrm{AQ} \text { (p. ex., évaluation axée sur la résolution de } \\
\text { problèmes, conception fondée sur des données probantes, } \\
\text { gestion du changement et de la mise en œuvre, évaluation } \\
\text { et amélioration du rendement, participation du patient, } \\
\text { engagement des prestataires, pérennité et diffusion, } \\
\text { élaboration d'une histoire à succès) }\end{array}$ \\
\hline $\begin{array}{l}\text { PEEA (cycles } \\
\text { Planifier- } \\
\text { Exécuter-Étudier- } \\
\text { Agir*) }\end{array}$ & $\begin{array}{l}\text { La majorité déclare avoir recours à } \\
\text { des cycles PEEA, mais présentent } \\
\text { peu de détails sur les expériences } \\
\text { des établissements au cours des } \\
\text { cycles PEEA, sur la manière dont } \\
\text { les cycles PEEA sont intégrés aux } \\
\text { efforts d'amélioration ou sur la } \\
\text { façon dont la collecte continue de } \\
\text { données éclaire le processus d'AQ }\end{array}$ & $\begin{array}{l}\text { N'a pas eu recours aux cycles PEEA } \\
\text { H A employé une approche commune en matière } \\
\text { d'amélioration (selon l'approche d'amélioration de la FCASS : } \\
\text { apprécier, concevoir, mettre en œuvre, évaluer [FCASS } \\
\text { 2014b]) et a fait appel à des questions de validation } \\
\text { (p. ex., votre PA produit-il ce que vous escomptiez? } \\
\text { Dans la négative, pourquoi pas?) }\end{array}$ \\
\hline
\end{tabular}


Une approche de collaboration à un problème de soins chroniques

Tableau 1. Description des composants structurels et axés sur les processus les plus courants des projets collaboratifs d'amélioration de la qualité (selon Nadeem et al. 2013) par rapport au modèle du projet collaboratif d'AQ COSA (suite)

\begin{tabular}{|c|c|c|}
\hline Composant & Description & Application au projet collaboratif d'AQ COSA \\
\hline Appels d'équipe & $\begin{array}{l}\square \text { Appels mensuels d'équipe } \\
\square \text { Participation de divers } \\
\text { établissements aux appels }\end{array}$ & $\begin{array}{l}\text { ■ Appels trimestriels d'équipe } \\
\text { Appels d'équipe généralement réservés à des rencontres } \\
\text { entre chaque équipe et le personnel de la FCASS, le } \\
\text { formateur et le mentor de l'équipe } \\
\text { IH Webinaires avec participation de nombreuses équipes } \\
\text { H Appels d'encadrement / de mentorat trimestriels, appels } \\
\text { réguliers avec le corps enseignant et appels trimestriels } \\
\text { du comité exécutif où un échange d'information se } \\
\text { produisaient entre les équipes }\end{array}$ \\
\hline $\begin{array}{l}\text { Soutien } \\
\text { électronique / } \\
\text { par courriel }\end{array}$ & $\begin{array}{l}\text { Soutien électronique ou par } \\
\text { courriel parfois offert, mais peu } \\
\text { d'informations quant à la mesure } \\
\text { dans laquelle les participants au } \\
\text { projet collaboratif d'AQ comptent } \\
\text { sur cet appui }\end{array}$ & $\begin{array}{l}\text { Q Plateforme d'apprentissage en ligne personnalisée, bilingue, } \\
\text { (surnommée « le Bureau virtuel de l'Atlantique ») pour les } \\
\text { équipes de la COSA, ses enseignants, ses formateurs et ses } \\
\text { mentors; en plus d'un soutien complémentaire par courriel }\end{array}$ \\
\hline \multirow[t]{2}{*}{ Processus d'AQ* } & $\begin{array}{l}\text { La majorité intègre la collecte } \\
\text { continue de données (p. ex., } \\
\text { indicateurs de rendement, rapports } \\
\text { continus sur les résultats visés) }\end{array}$ & $\begin{array}{l}\text { घ Les plans de mesure et de collecte de données recueillaient } \\
\text { des indicateurs particuliers aux équipes / aux PA et des } \\
\text { mesures du degré de collaboration y étaient également } \\
\text { incorporées } \\
\text { - Exemples d'indicateurs de PA : mesures } \\
\text { d'efficacité telles que l'acquisition de connaissances } \\
\text { et de compétences (chez le prestataire), le nombre } \\
\text { d'aiguillages vers un nouveau service, la mise en œuvre } \\
\text { d'ensembles d'ordonnances normalisés ; des mesures } \\
\text { concernant les soins centrés sur le patient et sa famille } \\
\text { telles que la satisfaction du client, I'auto-efficacité, } \\
\text { l'apport du patient aux processus de soins. } \\
\text { - Exemples d'indicateurs de collaboration : } \\
\text { la participation de l'équipe à des activités d'apprentissage } \\
\text { virtuelles; I'acquisition de connaissances et de } \\
\text { compétences de l'équipe; la satisfaction de l'équipe } \\
\text { (p. ex., par rapport au contenu de l'atelier et des } \\
\text { webinaires, à l'encadrement) ; expansion du réseau } \\
\text { des participants }\end{array}$ \\
\hline & $\begin{array}{l}\square \text { Dans certains cas, les enseignants } \\
\text { prodiguent des conseils aux } \\
\text { établissements et comptent sur un } \\
\text { soutien externe pour la synthèse } \\
\text { des données et la rétroaction }\end{array}$ & $\begin{array}{l}\square \text { Les enseignants, formateurs et mentors ont offert une } \\
\text { rétroaction continue aux équipes / rétroaction continue par } \\
\text { rapport aux PA et le personnel d'évaluation de la FCASS a } \\
\text { fourni du soutien et une rétroaction en matière de synthèse } \\
\text { des données }\end{array}$ \\
\hline \multirow[t]{2}{*}{$\begin{array}{l}\text { La participation } \\
\text { organisationnelle }\end{array}$} & $\begin{array}{l}\text { Vertains rendent compte de la } \\
\text { participation de la Direction de } \\
\text { l'organisation, mais il n'est pas clair } \\
\text { que ces dirigeants soient membres } \\
\text { de l'équipe d'AQ ou qu'ils } \\
\text { participent autrement }\end{array}$ & $\begin{array}{l}\text { Varticipation des dirigeants de l'organisation au moyen } \\
\text { d'un comité exécutif composé de hauts dirigeants }\end{array}$ \\
\hline & $\begin{array}{l}\text { च Peu d'exemples de projets } \\
\text { collaboratifs d'AQ qui ont pénétré } \\
\text { l'ensemble de l'organisation (p. ex., } \\
\text { la formation de personnel autre } \\
\text { que les membres de l'équipe du } \\
\text { projet collaboratif d'AQ assurée par } \\
\text { un enseignant du projet collaboratif } \\
\text { d'AQ ou des membres locaux du } \\
\text { projet collaboratif d'AQ) }\end{array}$ & $\begin{array}{l}\text { Matériel des ateliers / webinaires disponible à l'ensemble de } \\
\text { I'organisation, invitations aux ateliers à certains participants } \\
\text { choisis en dehors de l'équipe du projet collaboratif d'AQ } \\
\text { (p. ex., provenant de ministères de la santé et de partout } \\
\text { au Canada) et formation sur mesure assurée / appuyée par } \\
\text { la FCASS sur demande (p. ex., plusieurs ateliers / réunions } \\
\text { sur les soins chroniques dans la région de l'Atlantique) }\end{array}$ \\
\hline
\end{tabular}




\begin{tabular}{|c|c|c|}
\hline Composant & Description & Application au projet collaboratif d'AQ COSA \\
\hline \begin{tabular}{|l} 
Participation \\
préalable \\
au projet \\
collaboratif d'AQ
\end{tabular} & $\begin{array}{l}\text { Peu d'exemples d'activités } \\
\text { préalables (p. ex., utilisation « d'un } \\
\text { groupe d'experts », un groupe qui } \\
\text { établit des cibles d'amélioration } \\
\text { et des plans en matière de } \\
\text { collaboration, comme l'obtention } \\
\text { obligatoire d'un engagement } \\
\text { officiel ou l'application de critères } \\
\text { « de préparation ») }\end{array}$ & $\begin{array}{l}\text { Travail préalable exigeant que les équipes établissent un } \\
\text { plan pour leur PA qui satisfasse les critères de préparation ; } \\
\text { le personnel de la FCASS a également travaillé en étroite } \\
\text { collaboration avec le corps enseignant pour élaborer un } \\
\text { plan d'apprentissage (contenu des ateliers et feuilles de } \\
\text { travail) tout au long du projet collaboratif }\end{array}$ \\
\hline
\end{tabular}

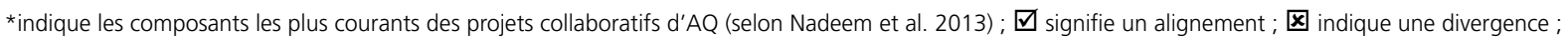
Ho indique une caractéristique supplémentaire

projet collaboratif d'AQ COSA (décrits dans le Tableau 1) étaient fondés sur deux modèles d'amélioration : l'approche d'amélioration de la FCASS (FCASS 2014a) en tant que modèle d'AQ et le CCM (modèle du MacColl Center for Health Care Innovation 2002) en tant que modèle de pratique fondée sur des données probantes. L'approche d'amélioration de la FCASS a orienté l'amélioration globale : le programme d'apprentissage et d'encadrement étant conçus dans le but de développer la capacité des équipes à apprécier le problème sous-jacent du système de santé, à concevoir une solution éclairée par des données probantes, à mettre en cuure le changement et à évaluer la différence que celui-ci produit. L'appréciation, la conception, la mise en œuvre et l'évaluation sont des compétences et des pratiques importantes en matière de leadership qui permettent d'évaluer les progrès de mise en ouvre d'un PA (voir le Tableau 2a pour consulter un résumé des progrès des équipes d'amélioration). L'approche d'amélioration de la FCASS comprend aussi des « leviers » qui permettent et accélèrent l'amélioration des soins de santé, par exemple, l'utilisation de données probantes pour éclairer les décisions à toutes les étapes du processus d'amélioration et la participation des patients et de leurs familles au réaménagement des soins (FCASS 2014a ; 2014b).
Le CCM (que ses auteurs appellent maintenant tout simplement le Modèle de soins) a offert un cadre pour comprendre les éléments de la conception d'améliorations à la PGMC. Ces éléments comprennent le soutien à l'autogestion $(\mathrm{SAG})$, la conception du système de prestation, l'aide à la décision et les systèmes d'information cliniques, ainsi que les ressources communautaires et les politiques (voir le Tableau 2a pour consulter un résumé des objectifs centraux et des éléments de conception des PA des équipes pour la prestation de soins chroniques).

Tandis que le projet collaboratif d'AQ COSA partage les caractéristiques de projets collaboratifs d'AQ existants, il présente plusieurs caractéristiques uniques :

- Partage de la gouvernance et des coûts. Un comité exécutif constitué de PDG et de VP des ASR de l'Atlantique régissait la Collaboration, de concert avec la Direction de FCASS (chef de la direction et vice-président des programmes), dont l'engagement a été officialisé par une charte qui établissait les objectifs, les activités, ainsi que d'autres éléments de la COSA (FCASS 2012a). La charte prévoyait une entente sur le partage des coûts, ainsi que la formalisation de l'intérêt de tous les membres pour 
Tableau 2a. Objectifs centraux des projets d'amélioration des équipes de la COSA et alignement sur le Modèle de soins chroniques (CCM) et l'Approche d'amélioration de la FCASS

\begin{tabular}{|c|c|c|c|c|c|c|c|}
\hline \multirow[b]{2}{*}{$\begin{array}{l}\text { Pro- } \\
\text { vince*/ } \\
\text { Équipe }\end{array}$} & & \multirow[b]{2}{*}{$\begin{array}{l}\text { Objectifs centraux du projet } \\
\text { d'amélioration }\end{array}$} & \multicolumn{5}{|c|}{$\begin{array}{l}\text { Progrès en matière d'amélioration } \\
\text { (selon l'Approche d'amélioration de la FCASS) }\end{array}$} \\
\hline & & & $\begin{array}{l}\text { Objectif central du Modèle } \\
\text { de soins chroniques / } \\
\text { éléments de conception }\end{array}$ & Apprécier & $\begin{array}{l}\text { Conce- } \\
\text { voir }\end{array}$ & $\begin{array}{l}\text { Mettre } \\
\text { en } \\
\text { œuvre }\end{array}$ & Évaluer \\
\hline \multirow[t]{2}{*}{ 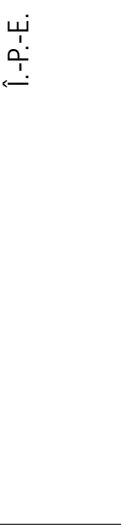 } & Health PEI & $\begin{array}{l}\text { - Comprendre les causes sous-jacentes } \\
\text { de l'incidence anormalement élevée des } \\
\text { affections sensibles aux soins ambulatoires } \\
\text { (ACSC) } \\
\text { - Élaborer un outil virtuel pour les échanges } \\
\text { patient-prestataire et pour le suivi du SAG } \\
\text { - } \text { Renseigner les patients atteints de maladie } \\
\text { pulmonaire obstructive chronique (MPOC) }\end{array}$ & $\begin{array}{l}\text { - } \text { SAG } \\
\text { - } \text { de prestation } \\
\text { - } \text { Aide à la décision } \\
\text { - } \text { Systèmes d'information } \\
\text { clinique } \\
\text { - } \text { Ressources } \\
\text { communautaires et } \\
\text { politiques } \\
\end{array}$ & 0 & 0 & $N$ & $\mathrm{~N}$ \\
\hline & Health PEI & $\begin{array}{l}\text { - Formation en SAG pour tous les cliniciens } \\
\text { de Health PEI (en commençant par les } \\
\text { prestataires de soins primaires et en } \\
\text { poursuivant avec les prestataires de soins } \\
\text { actifs) }\end{array}$ & $\begin{array}{l}\text { - } \text { SAG } \\
\text { - } \text { Conceptio la décision } \\
\text { de prestation }\end{array}$ & 0 & 0 & 0 & O \\
\hline \multirow[t]{2}{*}{$\begin{array}{l}\dot{m} \\
\dot{z}\end{array}$} & $\begin{array}{l}\text { Réseau de } \\
\text { santé Horizon }\end{array}$ & $\begin{array}{l}\text { - Évaluer le programme PEER } 126 \text { (Peers } \\
\text { Engaged in Education and Recovery) : } \\
\text { un service de réadaptation psychosociale } \\
\text { sensible à l'âge (pour les jeunes de } 16 \text { à } \\
29 \text { ans) et les programmes communautaires } \\
\text { visant à aider les jeunes à atteindre leurs } \\
\text { objectifs en matière de bien-être affectif, } \\
\text { social et psychologique }\end{array}$ & $\begin{array}{l}\text { - } \text { SAG } \\
\text { - Conception du système } \\
\text { de prestation } \\
\text { - } \text { Ressources } \\
\text { communautaires et } \\
\text { politiques }\end{array}$ & 0 & 0 & 0 & 0 \\
\hline & $\begin{array}{l}\text { Réseau } \\
\text { de santé } \\
\text { Vitalité }\end{array}$ & $\begin{array}{l}\text { - Évaluation des besoins en matière de soins } \\
\text { de santé primaires et établissement des } \\
\text { priorités dans quatre collectivités } \\
\text { - Participation communautaire et santé de la } \\
\text { population }\end{array}$ & $\begin{array}{l}\text { Ressources } \\
\text { communautaires et } \\
\text { politiques }\end{array}$ & $\mathrm{S} / \mathrm{O}^{1}$ & 0 & $\begin{array}{l}\text { En } \\
\text { cours }\end{array}$ & $N$ \\
\hline 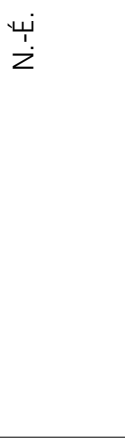 & $\begin{array}{l}\text { Nova Scotia } \\
\text { Health } \\
\text { Authority } \\
\text { (anciennement } \\
\text { Capital Health) }\end{array}$ & $\begin{array}{l}\text { - Modifier la schématisation de la chaîne de } \\
\text { valeur pour identifier les lacunes de soins } \\
\text { (état actuel) du point de vue du patient et } \\
\text { concevoir des améliorations de processus } \\
\text { pour combler ces lacunes (état futur) } \\
\text { - Réaménager les services de quatre } \\
\text { programmes de maladies chroniques dans } \\
\text { le but de rationaliser les processus et } \\
\text { d'améliorer la coordination des soins } \\
\text { - Conception du Corridor }{ }^{\complement} \text { et de la trousse } \\
\text { d'outils de Prévention et de gestion des } \\
\text { maladies chroniques (PGMC) }\end{array}$ & $\begin{array}{l}\text { - } \text { SAG } \\
\text { - } \text { de prestation } \\
\text { - } \text { Aide à la décision } \\
\text { - Systèmes d'information } \\
\text { clinique } \\
\text { - Ressources et soutien } \\
\text { communautaires }\end{array}$ & 0 & 0 & $\begin{array}{l}\text { En } \\
\text { cours }\end{array}$ & $\mathrm{N}$ \\
\hline 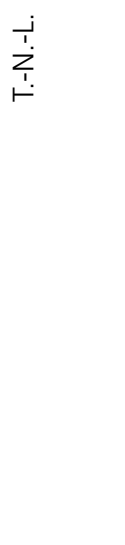 & Central Health & $\begin{array}{l}\text { - Créer des ordonnances permanentes et } \\
\text { des cheminements de soins et former les } \\
\text { prestataires par rapport aux programmes } \\
\text { de soins respiratoires existants } \\
\text { - Convertir la clinique de l'asthme du centre } \\
\text { de santé local en centre ambulatoire de } \\
\text { soins respiratoires pour adultes et informer } \\
\text { les prestataires de soins de l'existence de } \\
\text { ses programmes } \\
\text { - Élaborer un programme de sensibilisation à } \\
\text { la MPOC fondé sur le Programme INSPIRED } \\
\text { de sensibilisation à la MPOCTM, obtenir } \\
\text { les ressources nécessaires et informer les } \\
\text { prestataires de soins de ses bienfaits pour } \\
\text { les patients }\end{array}$ & $\begin{array}{l}\text { - } \text { SAG } \\
\text { - Conception du système } \\
\text { de prestation } \\
\text { - Aide à la décision } \\
\text { - } \text { Ressources } \\
\text { communautaires et } \\
\text { politiques }\end{array}$ & 0 & 0 & 0 & 0 \\
\hline
\end{tabular}


Tableau 2a. Objectifs centraux des projets d'amélioration des équipes de la COSA et alignement sur le Modèle de soins chroniques (CCM) et l'Approche d'amélioration de la FCASS (suite)

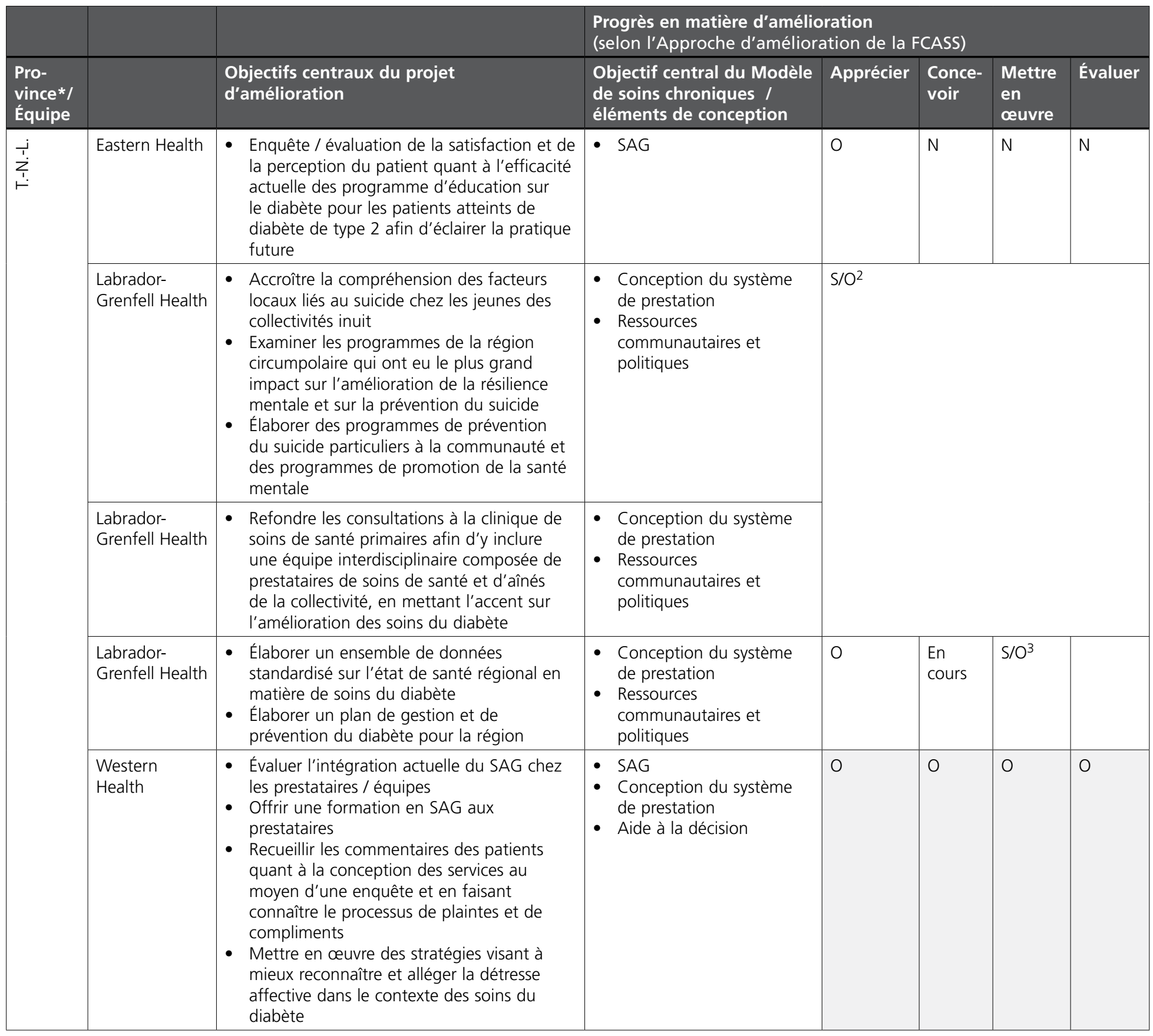

*l'île-du-Prince-Édouard (î.-P.-É.), le Nouveau-Brunswick (N.-B.), la Nouvelle-Écosse (N.-É.) et Terre-Neuve-et-Labrador (T.-N.-L.)

1. $S / O=$ sans objet ; l'équipe de Vitalité avait déjà entrepris l'évaluation avant son inscription à la COSA.

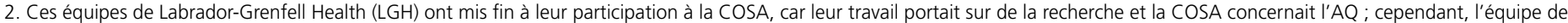

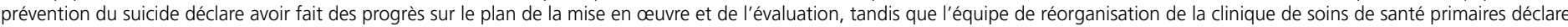
avoir fait des progrès en matière de mise en œuvre.

3. En conséquence de la note 2, cette équipe de LGH s'est jointe à la COSA plus tardivement que les autres équipes. 
l'élaboration, la prestation et les résultats de la COSA. L'entente comportait la contribution des ASR aux coûts associés à la participation de leurs équipes à l'atelier et à la rémunération des enseignants / formateurs, ainsi que des ressources nécessaires pour réaliser les PA localement. Selon le mandat et les attributions de l'entente, la présidence du comité de gouvernance est tournante (actuellement, elle est assurée par le chef de la direction de Health PEI, qui a fourni ses commentaires sur ce projet) et le personnel de la FCASS (directrice principale et agente de liaison régionale) s'acquitte des activités liées à son secrétariat.

- Dépendance par rapport à l'expertise et aux besoins régionaux. En s'appuyant sur une analyse des priorités stratégiques locales, telles que définies par les provinces et les ASR de l'Atlantique (Akunov et Leith 2012), les dirigeants du secteur de la santé ont choisi la PGMC centrée sur le patient et sa famille en tant qu'objectif central du projet collaboratif d'AQ COSA. D'entrée de jeu, on souhaitait solliciter la participation d'équipes interrégionales et interprovinciales aux PA. Toutefois, cela ne s'est pas concrétisé. La FCASS a travaillé avec les dirigeants de chaque région sanitaire, qui ont, à tour, défini des objectifs d'amélioration particuliers à leur région, constitué des équipes et conçu des PA. D'aucuns décriraient le processus comme une approche faible en règles, puisque le Comité exécutif s'est fié à des cadres intermédiaires et à des prestataires de soins de santé pour définir les PA selon les besoins de leurs populations de patients, sous le dénominateur commun de la PGMC. Par ailleurs, toujours conformément à une approche d'ordre régional, la COSA a organisé un atelier pour les équipes dans chacune des quatre provinces de
l'Atlantique, a fait venir la majorité de ses ressources d'encadrement / de mentorat de la région de l'Atlantique et a intégré une fonction de liaison régionale (membre du personnel de la FCASS) à Moncton, N.-B., afin de servir de principal point de chute de la COSA. Compte tenu de la nécessité d'offrir le programme en anglais et français, la COSA revêtait une nature bilingue.

- L'accent sur le raccordement entre la prestation et les politiques. Bien que les ministères provinciaux de la santé n'aient jamais formellement été signataires de la Charte ni membres du comité exécutif (conformément à la décision du comité visant à faire de la Collaboration une intervention au niveau de la prestation et qu'elle soit régie de la sorte), la COSA a accordé une attention particulière à l'établissement de liens avec les décideurs en leur donnant la possibilité de participer à des ateliers (p. ex., un ministre de la santé et d'autres hauts fonctionnaires ont accepté d'accueillir les participants dans le cadre d'un discours liminaire et des responsables de l'élaboration des politiques ont participé aux quatre ateliers) et à certaines délibérations du comité exécutif (p. ex., des responsables des politiques ont contribué à éclairer la charte en plus de participer, sur invitation, à plusieurs réunions de gouvernance). $\mathrm{La}$ FCASS a également accepté des demandes de préparation ou d'animation de séances d'information et d'orientation auprès des ministères de la santé, de façon continue et selon les besoins. Ces activités, bien que vastes, n'ont pas encore abouti à des modifications de la politique ni influencé des décisions stratégiques; en revanche, elles ont servi à créer une voie de communication en vertu de laquelle des améliorations au niveau de la prestation éclairent le milieu des politiques. 
- Déploiement d'un réseau de soutien pour les équipes comprenant de l'encadrement et du mentorat. Pour aider les équipes à se fixer des buts réalistes, à faire des progrès mesurables et à obtenir des résultats en temps opportun, la COSA a consacré un soutien propre au projet. En plus de la coordination et de l'élaboration du programme d'apprentissage offerts par le personnel et le corps enseignant de la FCASS, la COSA a donné à chaque équipe l'accès à un mentor universitaire et à un formateur en amélioration : des conseillers externes qui ont prodigué des conseils personnalisés aux équipes au cours de la Collaboration. Les mentors universitaires étaient des chercheurs chevronnés en recherche appliquée et des praticiens disposant d'un éventail de compétences et d'expertises qui ont aidé les équipes à formuler leur énoncé de problème, à choisir leur méthodologie et à déterminer les exigences de leur projet en matière de données ; en plus de les aider à comprendre l'évaluation systématique et l'application des données probantes issues de la recherche à des initiatives d'amélioration. Les formateurs en amélioration étaient des dirigeants ou des cliniciens chevronnés du secteur de la santé qui ont aidé les équipes à gérer le changement et à appliquer des approches tactiques et stratégiques en vue d'efficacement mettre en ouvre leur PA. Les formateurs et les mentors étaient en mesure d'établir des liens avec les équipes et, par conséquent, de développer leur expertise et leurs réseaux locaux. Les formateurs et les mentors de la COSA ont contribué une vaste expertise issue d'une gamme de disciplines du domaine de la santé (notamment les soins infirmiers, la médecine, la psychologie, la pharmacie et d'autres professions de la santé), de l'élaboration des politiques et de la prise de décisions (par exemple, d'anciens PDG de régions sanitaires), ainsi que des milieux de la recherche (notamment en économie, en gouvernance, en évaluation et en aide à la décision).

\section{Évaluer la COSA et ses principaux enseignements}

Les plans de suivi et d'évaluation de la COSA ont été élaborés par le personnel de la FCASS et validés par ses enseignants, ses formateurs et ses mentors (Phillips et al. 2013). Des conseillers externes, partenaires de la FCASS, ont réalisé l'évaluation finale qui reposait sur une variété de sources de données (l'analyse de documents, des enquêtes post-atelier, des entretiens avec des informateurs clés, des enquêtes sur l'analyse des réseaux sociaux et une discussion de groupe avec le personnel de la FCASS (Champagne et al. 2015). Toutes les constatations de cette section sont tirées de l'évaluation finale, complétées par des observations portant sur chacun des objectifs du projet collaboratif d'AQ COSA : i) l'élaboration d'une approche centrée sur le patient et sa famille pour gérer et prévenir les maladies chroniques ; ii) la création d'un réseau d'équipes organisationnelles, régionales et provinciales en vue de partager des solutions systémiques éclairées par des données probantes et de travailler ensemble à l'élaboration, à la mise en œuvre et à la pérennisation d'initiatives d'amélioration ; et iii) la promotion de la pérennité des systèmes de santé.

\section{Créer une approche centrée sur le patient et sa famille en matière de gestion des maladies chroniques \\ Quatre équipes (des huit qui ont participé pleinement à la COSA) ont mis en ouvre et évalué leur PA au cours de la durée de la COSA (voir les Tableaux 2a et 2b). Conformément à l'objectif de la Collaboration}




\section{Tableau $2 \mathrm{~b}$. Les étapes clés des quatre équipes de la COSA qui ont réussi à mettre en œuvre et à évaluer leurs projets d'amélioration}

\begin{tabular}{l|l} 
Équipe & Jalons du projet d'amélioration
\end{tabular}

\begin{tabular}{|c|c|}
\hline Health PEI & $\begin{array}{l}\text { - } 105 \text { prestataires de soins de santé ciblés (sur les 1 } 000 \text { des trois prochaines années) ont terminé ou } \\
\text { suivent actuellement une formation sur le SAG et d'autres cliniciens sont sur une liste d'attente pour } \\
\text { suivre cette formation à l'avenir. Les enquêtes post-atelier révèlent ce qui suit : } \\
\text { - La grande satisfaction des prestataires quant à la formation et à son contenu, entre autres concernant } \\
\text { les outils pour le patient / sa famille, les exemples concrets et l'application pratique de la formation } \\
\text { - La confiance des prestataires quant à leur compétences en matière de SAG, ce qui suppose une plus } \\
\text { grande probabilité de mettre en œuvre les techniques de modification des comportements de SAG } \\
\text { dans la pratique } \\
\text { - La capacité des prestataires de citer au moins deux changements de comportement qu'ils apporteront } \\
\text { dans leur pratique ; les changements les plus couramment cités étant : } \\
\text { 1. Poser plus de questions et mieux écouter } \\
\text { 2. Évaluer la réceptivité du patient au changement sans porter de jugement } \\
\text { 3. Fixer des objectifs avec les patients et identifier les obstacles au changement } \\
\text { 4. Appliquer les outils (p. ex., échelle d'importance / de confiance, équilibre décisionnel, }\end{array}$ \\
\hline
\end{tabular}

Réseau de santé Horizon

- Les enquêtes ciblant les préoccupations selon 14 domaines de la vie pré- et post-PEER 126 montrent que les jeunes auto-signalent des améliorations dans tous les secteurs (notamment la santé mentale, le travail, les relations interpersonnelles et l'argent), à l'exception de la spiritualité.

- Les jeunes participants de PEER 126 déclarent atteindre leurs buts ou faire des progrès en ce sens (p. ex., les domaines de l'amitié et des activités sont l'objet des progrès les plus importants, tandis que les participants eux-mêmes déclarent développer les compétences nécessaires à l'obtention d'un emploi futur, selon le domaine de la « vie active »).

- Les données sur l'utilisation des soins de santé montrent que les jeunes participants de PEER 126 ont moins visité les urgences, les services de santé mentale communautaires mobiles et les hôpitaux pour un diagnostic de troubles mentaux (comparativement à leur situation préalable à PEER 126).

Central - L'ancienne clinique externe de l'asthme a été transformée en centre de soins respiratoires, où l'on Health utilise un cheminement de neuf mois qui combine la gestion médicale sur place et la sensibilisation à I'autogestion afin de combler un besoin jusqu'à présent mal desservi pour la MPOC légère à modérée (60 patients ont été vus dans l'intervalle des deux mois depuis l'ouverture).

- Une version locale du programme INSPIRED de sensibilisation à la MPOC TM a été créée pour les patients atteints d'une MPOC avancée et leurs familles. Le programme cible les patients souffrant de MPOC qui ont été hospitalisés et leur offre un programme de soutien à domicile, comprenant la sensibilisation à I'autogestion, I'élaboration de plans d'action, un soutien psychosocial et, le cas échéant, la planification préalable des soins.

Western $\quad$ - Conformité de $100 \%$ selon une vérification concernant la mise en œuvre d'un outil de dépistage de la Health dépression chez les personnes atteintes de diabète de type 2.

- Personnel formé par rapport à la nouvelle " politique de compliments et de plaintes » visant à solliciter des commentaires de la part de patients ; et les patients ont été interrogés quant aux points forts du programme, qui comprennent les éléments suivants :

- Prestataire bien informé, compétent, respectueux, courtois et serviable

- Rendez-vous commodes, facilement obtenus

- Plans de gestion du diabète utiles, séances de sensibilisation et rendez-vous

- Confiance déclarée par les patients eux-mêmes en matière de gestion du diabète, notamment par rapport à une saine alimentation, aux activités quotidiennes et aux rendez-vous avec le médecin.

- Compétences essentielles de l'équipe déterminées et formation en SAG amorcée

- Résultats de l'évaluation des ressources en soins de santé primaires et du soutien à la prise en charge des maladies chroniques (PCRS) réalisée pré- et post- processus susmentionnés montrent des améliorations à tous points de vue, à savoir :

- Santé affective - six des sept équipes ont atteint ou dépassé la cible de changement de 2,0 dont une amélioration du score de suivi de $\sim 4,5$ points

- Apport du patient - toutes les équipes ont atteint ou dépassé la cible de 2,0 dont un changement de $\sim$ 4,3 points dans l'amélioration du score de suivi

- Formation du médecin, de l'équipe et du personnel en matière d'autogestion : six des sept équipes ont dépassé l'objectif de changement de 2,0 dont une amélioration du score de suivi de 4,1-points ; la $7^{e}$ équipe ayant rapporté un changement de 1,0. 
Tableau 3. Principales conclusions associées à la mise en œuvre d'approches de prévention et de gestion des maladies chroniques centrées sur le patient et sa famille

\begin{tabular}{|c|c|c|}
\hline & Principales constatations \\
\hline \multirow[t]{3}{*}{$\begin{array}{l}\text { Éléments } \\
\text { du système } \\
\text { de santé } \\
\text { du Modèle } \\
\text { de soins } \\
\text { chroniques }^{1}\end{array}$} & $\begin{array}{l}\text { Soutien à } \\
\text { l'autogestion }\end{array}$ & $\begin{array}{l}\text { - La participation du patient est une condition préalable à l'autogestion. } \\
\text { - La sensibilisation et l'acceptation du prestataire en ce qui concerne la nécessité } \\
\text { - et l'utilité de l'autogestion s'imposent. } \\
\text { - Le changement des comportements des prestataires de soins de santé est un } \\
\text { - La confiance mutuelle entre prestataire et patient est fondamentale. } \\
\text { - Le renforcement de la confiance des prestataires concernant leurs compétences } \\
\text { - et le soutien au travail d'équipe sont importants pour promouvoir l'autogestion. } \\
\text { - Le SAG devrait être intégré à la prestation des soins habituels. } \\
\text { - L'accès à des outils pour les patients et les prestataires est essentiel à la } \\
\text { pérennisation de la pratique de l'autogestion. }\end{array}$ \\
\hline & $\begin{array}{l}\text { Conception } \\
\text { du système de } \\
\text { prestation }\end{array}$ & $\begin{array}{l}\text { - Les patients fournissent un apport important dans le cadre de la conception } \\
\text { conjointe des soins, notamment des observations inattendues sur la façon } \\
\text { d'organiser et de prodiguer les soins. }\end{array}$ \\
\hline & $\begin{array}{l}\text { Aide à la } \\
\text { décision }\end{array}$ & $\begin{array}{l}\text { - L'adaptation des services aux besoins des patients en temps réel est essentielle à } \\
\text { la mise en place de systèmes de soins adaptés. } \\
\text { - Un suivi et une surveillance appropriés de l'assiduité des patients et des taux } \\
\text { d'attrition des programmes sont importants pour mieux adapter les services. }\end{array}$ \\
\hline $\begin{array}{l}\text { Aspect } \\
\text { communautaire } \\
\text { du Modèle } \\
\text { de soins } \\
\text { chroniques }\end{array}$ & $\begin{array}{l}\text { Ressources } \\
\text { communau- } \\
\text { taires et } \\
\text { partenariats }\end{array}$ & $\begin{array}{l}\text { - La collaboration communautaire est fondamentale à l'accroissement de la } \\
\text { participation des patients aux changements de comportement. } \\
\text { - Le travail en partenariat avec des gens provenant de programmes distincts, } \\
\text { aux expériences diverses, peut contribuer à mieux intégrer les soins. }\end{array}$ \\
\hline
\end{tabular}

1. II n'y a aucune référence pour le quatrième élément des systèmes de santé (systèmes d'information cliniques) puisque l'évaluation de la COSA n'a révélé aucun constat important en la matière.

(de créer des soins centrés sur le patient et sa famille à l'égard de la gestion et la prévention des maladies chroniques), ces quatre équipes ont mis en œuvre des éléments du CCM relatifs au $\mathrm{SAG}$, à la conception du système de prestation, à l'aide à la décision, aux ressources communautaires et aux partenariats (voir le Tableau 3). Concernant le SAG, en particulier, les conclusions de la COSA révèlent que l'élaboration de cet élément du CCM dépend d'un ensemble de conditions et de prédispositions, dont les suivantes :

- prioriser la participation du patient d'emblée : par exemple, un membre d'une équipe a déclaré qu'en posant la question aux patients, son équipe avait identifié un besoin particulier et pouvait à présent élaborer des programmes pour y répondre. Il rajoutait qu'il n'aurait jamais lui-même choisi ce besoin.
- mettre l'accent sur une plus grande conscience de la part des prestataires de l'importance de l'autogestion : par exemple, un membre d'une équipe a signalé que le soutien à l'autogestion devrait être intégré au fonctionnement actuel du système de soins de santé et aux soins habituels ; cela ne devrait pas être une nouvelle initiative réalisée en vase clos, mais plutôt l'occasion de construire un projet commun pour divers services.

- offrir du soutien aux prestataires de services en faveur du changement de certains comportements grâce au développement des compétences : par exemple, un membre d'une équipe a indiqué que chez les prestataires, la perception de leur rôle à l'égard des patients avait changé : pour certains, elle était passée d'un rôle de responsable du changement de comportement chez le patient à celui 
de responsable d'encourager le patient à changer.

\section{Construire un réseau pour partager des solutions et œuvrer à l'amélioration des soins chroniques}

L'expérience des systèmes de santé dans le cadre de tentatives visant à améliorer les soins laisse supposer que ces systèmes luttent constamment contre l'inertie du régime : " la tendance qu'ont les systèmes à continuer à faire la même chose sans tenir compte des circonstances changeantes "(Coeira $2011: 27)$. La COSA proposait un environnement d'amélioration accueillant. Les conclusions de l'analyse des réseaux sociaux de la COSA montrent que le collectif offrait aux participants la possibilité d'élargir leurs réseaux locaux, interrégionaux et interprovinciaux. De l'enquête de référence à l'enquête de suivi, des améliorations sont manifestes pour les types de liens (dans les catégories savoir, partager et collaborer, qui, comme leur nom l'indique, évaluent la mesure dans laquelle les participants se connaissaient l'un l'autre, l'information qu'ils partagent les uns avec les autres ou la mesure dans laquelle ils collaborent les uns avec les autres ; dans l'analyse, les données ont également été examinées en fonction de toutes les catégories, en plus de l'ajout d'une quatrième catégorie, soit l'ensemble). La densité du réseau a au moins doublé pour tous les types de liens, tout comme le nombre de liens (par personne) et leur degré moyen (la profondeur du lien). Le réseau du savoir a affiché la plus forte hausse, soit 132 nouveaux liens tissés de la date de référence à la date de suivi ; toutefois, proportionnellement, le réseau du partage a connu la plus forte croissance : 2,67 fois plus de liens au cours de la même période. Il convient de noter que la FCASS a favorisé la création des liens les plus étroits au départ, puisque les équipes se sont senties plus étroitement liées à l'expertise locale des enseignants, des formateurs et des mentors.
Le réseautage était, par ailleurs, aussi perçu comme une composante positive du projet collaboratif d'AQ COSA. Lors du second atelier, $76 \%$ des participants ont indiqué que les occasions de réseautage étaient soit « très bonnes » ou " excellentes "; lors du troisième atelier, $84 \%$ ont déclaré que les ateliers leur avaient permis de cerner des possibilités de collaboration. La rétroaction des participants a permis d'élucider l'apport du réseautage en personne. Un participant a déclaré : « nous sommes habitués aux cloisons ; [l'atelier] a permis d'ouvrir des frontières. Il nous a donné un espace partagé. Nous avons beaucoup appris des autres équipes. »Un autre a déclaré : «nous avons appris à établir des liens avec les employés d'autres ministères et autorités régionales de la santé. Mon collègue ne travaille pas pour le même ministère, ce qui signifie que nous travaillons à présent en dehors de nos cloisons. " Les ateliers ont également été l'occasion de « ne vivre ses inquiétudes seul », comme un informateur le signalait, en créant une tribune pour le partage de préoccupations communes et pour œuvrer à la réalisation d'objectifs communs.

Une série de facteurs favorables et défavorables ont influencé la capacité de créer un environnement propice à l'amélioration (voir le Tableau 4). Lappui des dirigeants est important pour aligner les politiques organisationnelles ou provinciales sur les efforts d'amélioration du terrain. Étant donné que les prestataires créent des routines pour leur travail quotidien, il apparaît utile d'obtenir l'appui des ressources externes (p. ex., la FCASS en tant que facilitateur de l'amélioration ou des universitaires et des praticiens en tant que mentors et formateurs) afin de faciliter le changement de pratiques et de modèles de soins.

En outre, les prestataires et les organisations pouvaient compter sur une approche souple et personnalisée pour développer leurs capacités et intervenir en temps opportun (p. ex., grâce 


\begin{tabular}{|c|c|}
\hline Facteurs d'influence & Principales constatations \\
\hline Favorables & $\begin{array}{l}\text { - Soutien pour la Collaboration de la part des autorités dirigeantes du système } \\
\text { - Alignement de PA sur les objectifs stratégiques généraux de l'organisation } \\
\text { - Soutien initial et continu de la part de la haute direction } \\
\text { - Disponibilité et soutien d'une organisation externe (FCASS), notamment au début de la } \\
\text { - Mhase d'élaboration du projet } \\
\text { - Modèle de gouvernance de la FCASS : soutien à la médiation de conflits, notamment par } \\
\text { la communication et la coordination entre les membres de l'équipe ; fonction de liaison } \\
\text { régionale basée dans la région de l'Atlantique comme personne ressource principale ; } \\
\text { conseils stratégiques prodigués aux équipes } \\
\text { - Importance de l'intégration du point de vue des prestataires et des patients à l'évaluation } \\
\text { - Intégration précoce des indicateurs et des mesures dès l'élaboration de l'initiative }\end{array}$ \\
\hline Défavorables & $\begin{array}{l}\text { - Manque d'investissements internes dans les efforts d'amélioration continue (temps et } \\
\text { ressources financières) } \\
\text { - Membres de l'équipe faisaient face à des priorités et à des demandes concurrentes } \\
\text { - Faible disposition à chercher des données probantes ou absence d'une culture de } \\
\text { l'évaluation pour appuyer la conception d'un PA rigoureux }\end{array}$ \\
\hline
\end{tabular}

au concours d'une partie indépendante) en cas de situation à risque élevé (p. ex., si une équipe subissait le roulement de son chef d'équipe). Lapproche participative adoptée par la COSA semble favoriser la combinaison de diverses sources de connaissances expérientielles et les données probantes issues de la recherche provenant de disciplines et de traditions de recherche variées. Toutefois, les avantages potentiels de ce projet collaboratif d'AQ sont affaiblis par le risque que les prestataires et les organismes deviennent dépendants de cette aide extérieure ou distraits par la pression exercée par des demandes concurrentes.

Sur le plan des enseignements, en vue d'entreprendre et d'appuyer l'AQ au sens large, l'expérience (de toutes les équipes) de la COSA a permis de tirer des leçons sur la mise en œuvre, le développement des compétences et la facilitation de l'AQ (par l'intermédiaire d'un projet collaboratif d'AQ).

\section{Mise en ouvre}

Les résultats de la COSA laissent supposer que la réussite de la mise en œuvre des améliorations de la PGMC exige un ensemble de conditions et de prédispositions. Dans la mesure où l'organisation dispose déjà des attitudes et des comportements favorables aux soins chroniques, par exemple, les équipes seront peut être mieux outillées pour entreprendre et mener à bien l'amélioration des soins chroniques. Étant donné que seule la moitié des équipes sont passées à la mise en ouvre de leur initiative au cours de la Collaboration (voir le Tableau 2a), il est possible que ces équipes aient eu des conditions plus favorables ou aient été mieux équipées pour relever les défis éventuels que les équipes qui ne sont pas parvenues à la mise en œuvre (Parry et al. 2013). Or, dans le cas d'une équipe qui n'a pas amorcé la mise en œuvre de son projet, l'environnement n'était pas le facteur restrictif; plutôt, l'ampleur de l'initiative exigeait plus de temps que l'échéance permise par la COSA. Dans l'ensemble, les résultats indiquent que la mise en œuvre de l'amélioration des soins chroniques dans les milieux de pratique réels exige beaucoup de temps et d'effort, comme les études portant sur la réussite des efforts d'AQ l'avaient déjà révélé (Parry et al. 2013). Selon les résultats de la COSA, les principaux facteurs associés à la mise en œuvre sont : 
- La continuité et le soutien continu de la haute direction pour offrir de meilleurs soins aux personnes atteintes de maladies chroniques, en dépit de demandes concurrentes

- La continuité du personnel (en termes de roulement des ressources)

- Le temps réservé à l'élaboration de nouvelles approches de prestation de soins

- Des équipes multidisciplinaires disposant d'une expertise clinique et d'AQ (plus précisément en matière d'évaluation)

- Une forte culture de l'AQ et de l'évaluation au sein de l'organisation d'accueil du projet

- Une communication continue caractérisée par une compréhension commune de la mission et une confiance mutuelle entre les prestataires et la Direction

- Une vision commune de l'amélioration des soins pour les patients atteints de maladies chroniques permettant de mettre en place des soins centrés sur le patient et sa famille

- Des objectifs et des échéanciers réalistes, assortis d'un engagement à s'améliorer

Selon l'un des informateurs clés, « le principal apprentissage [fut] la participation et l'obtention de l'engagement des dirigeants dès le début, de sorte que les équipes bénéficiaient de l'appui nécessaire pour faire leur travail. » Bien que la Collaboration se centrait sur le niveau de la prestation, certains participants ont noté que le contexte plus général des politiques importait et que la Collaboration aurait profité d'une participation plus active des responsables des politiques. Les participants ont également souligné que les patients « n'ont pas suffisamment participé » et devraient être "plus présents ». La FCASS a encouragé les équipes à inviter des patients et des membres de leurs familles à participer aux ateliers et à solliciter leur participation active aux efforts de remaniement de la prestation des soins.
Toutefois, la participation limitée des patients et de leurs familles, dans l'ensemble, montre que celle-ci doit délibérément être intégrée à la conception du projet collaboratif.

Ces facteurs clés de la mise en œuvre, parmi d'autres, cadrent bien avec le contexte commun et réceptif des «systèmes de santé très performants ", caractérisés par une grande stabilité (faible taux de roulement) de la Direction et du personnel ; une bonne communication entre les gestionnaires et les cliniciens ; un investissement (en temps et en ressources) dans les processus d'amélioration ; ainsi qu'une orientation stratégique axée sur l'amélioration, en plus d'une culture de l'amélioration, notamment un accent prononcé sur la mesure du rendement et l'évaluation (Baker et al. 2008 ; Baker et Denis 2011).

\section{Compétences et aptitudes}

En ce qui concerne les domaines de l'éducation et de la formation, des aspects fondamentaux du projet collaboratif d'AQ COSA, on s'accorde à reconnaître qu'avant que des résultats ne puissent être observés (p. ex., l'organisation a-t-elle amélioré son rendement ?), des changements sont susceptibles d'être constatés sur le plan de l'expérience, de l'apprentissage et du comportement (Kirkpatrick et Kirkpatrick 2006). En termes de comportement, le Tableau 2a indique si les équipes ont été en mesure d'apprécier, de concevoir, de mettre en œuvre et d'évaluer leur projet. En matière d'expérience et d'apprentissage, les participants ont déclaré avoir perfectionné leurs aptitudes et compétences dans les domaines suivants :

- Communication - Les participants ont évoqué la nécessité de constamment partager et renforcer les objectifs et les méthodes de leur PA auprès de leur organisation d'attache, surtout si un changement dans la composition de 
l'équipe ou de son chef se produisait, et de veiller à ce que leur PA reste «bien en vue » à titre de priorité organisationnelle.

- Engagement communautaire - Les membres des équipes ont indiqué qu'ils avaient acquis de nouvelles connaissances quant à la façon de mobiliser leurs collectivités respectives, à savoir qui faire participer et comment recueillir des données pour éclairer la conception de nouveaux services ou de services existants.

- Gestion de projet - Les participants ont signalé que le PA, en particulier, était enrichissant, car il fournissait une démonstration pratique et appliquée de la gestion de projets (de la conception et de la planification jusqu'à l'exécution et le suivi des progrès). La souplesse permettant le choix de moyens d'exécution locaux permettait également de comprendre qu'on pouvait atteindre un objectif au moyen de méthodes variées de gestion de projets, tant que la volonté de le mener à bien était ferme.

- Évaluation - Les participants ont indiqué avoir beaucoup appris sur les méthodes et les pratiques d'évaluation (p. ex., les moyens de normaliser les objectifs, les mesures et les cibles d'un PA), or un grand nombre d'entre eux ont indiqué que cela les avait conduit à prendre conscience de l'absence de compétences ou de capacités au sein de leur organisation en matière d'évaluation efficace. Un des participants signalait, par exemple : «J'ai beaucoup appris au sujet de l'évaluation et j’ai réalisé que je n'étais pas très renseigné [...]. Il faut s'assurer de faire participer des personnes compétentes d'entrée de jeu. » Ainsi, les équipes qui ont été en mesure de montrer des résultats (comme l'indique le Tableau 2b) comptaient des membres disposant déjà d'une expertise en évaluation ou ont pu recruter cette expertise localement. Par ailleurs, au moins un autre organisme disposait de cette expertise, mais la portée et le champ d'application de son projet étaient les facteurs restrictifs, non pas l'absence d'une expertise en matière d'évaluation.

- Mise en œuvre et diffusion - Les enquêtes post-atelier montrent que la majorité des participants (89\%) conviennent que les documents des ateliers ont contribué à améliorer leur compréhension de l'élaboration d'une théorie du changement, de la façon de concevoir et de mettre en œuvre un PA, des moyens de remanier les soins de santé et d'identifier les défis et les possibilités en matière de participation du patient et du prestataire. Ces enquêtes révèlent également que les participants ont accru leurs compétences en matière de pérennité et de diffusion (97\%) et ont renforcé leur compréhension des méthodes de diffusion des meilleures pratiques (85\%). Une enquête menée auprès des formateurs et des mentors donne à penser que la COSA a augmenté la confiance des prestataires par rapport à la réalisation de changements. «Elle a fourni les étapes et le soutien nécessaires pour que les gens, les organismes et les groupes, qui avaient très peu de confiance en leur capacités au départ, passent à la mise en œuvre » déclarait un formateur, tandis qu'un autre affirmait : « un important renforcement des capacités s'est produit tant à l'échelle individuelle qu'au niveau des équipes. »

- Travail d'équipe multidisciplinaire La pratique consistant à entreprendre un PA en équipe, en particulier, a fourni un milieu appliqué où développer une sensibilisation aux approches multidisciplinaires et a remis en question les croyances existantes quant à ce que le travail d'équipe est apte à réaliser. Par exemple, un participant a déclaré avoir appris que les médecins sont en fait ouverts à l'évolution 
des pratiques, tandis qu'un autre a affirmé que le travail d'équipe avait servi de rappel à l'effet que les soins centrés sur le patient et sa famille devraient faire partie des descriptions de tâches.

\section{Facilitation de l'AQ}

Les participants ont rapporté des expériences positives quant aux composants de cette Collaboration (décrits dans le Tableau 1). Parmi les facteurs qui appuient les projets collaboratifs d'AQ, on retrouve :

- Un soutien / programme d'apprentissage personnalisé qui respecte le stade d'avancement des équipes et leur PA

- Un complément de soutien (tiers) dans les situations à risque élevé, comme le roulement du personnel

- Un encadrement/modèle de mentorat qui combine une expertise complémentaire (théorique et pratique dans ce cas)

- La promotion des principes fondamentaux de l'amélioration efficace des soins chroniques à l'ensemble du système de santé (de la prestation aux politiques)

- La nécessité de mieux communiquer les progrès et les résultats du $\mathrm{PA}$ auprès des gestionnaires et des collègues sur une base continue

- La compréhension des forces et des faiblesses des membres de l'équipe (p. ex., la collecte de données, l'évaluation, l'établissement de partenariats communautaires, le travail d'équipe) afin d'élaborer des programmes d'apprentissage adaptés à leurs besoins.

Les participants estimaient que les ateliers, les webinaires et les autres éléments du programme d'apprentissage étaient utiles (dont le contenu est résumé au Tableau 1). « Le programme d'enseignement était vraiment très bien », signalait un participant qui ajoutait :
« les outils et les processus de travail pour comprendre ces enjeux sont très utiles. » Les données d'enquête recueillies tout au long de la Collaboration corroborent ce constat. Par exemple, $74 \%$ des participants ont indiqué que les quatre ateliers étaient « très bien » ou « excellents » dans l'ensemble. Après chaque atelier, les participants évaluaient des éléments particuliers. Par exemple, lors du quatrième atelier, les éléments suivants ont reçu la mention «très bien » ou « excellent » : contenu de l'atelier (85\%), organisation de l'atelier (88\%), enseignants / conférenciers invités (88\%), rythme de prestation du contenu (82\%) et participation des participants (85\%). Lapplication des feuilles de travail et des outils a reçu un score sensiblement plus faible (70\%), bien que ce classement inférieur pourrait être attribuable au fait que les équipes n'aient bénéficié que d'une brève introduction à ces feuilles de travail et à ces outils lors de l'atelier, en dépit du fait qu'elles devaient être remplies et renvoyées après l'atelier.

Le modèle d'encadrement « double » (les équipes pouvant compter sur l'appui à la fois d'un mentor universitaire et d'un formateur en amélioration) était fort apprécié. Dans le cadre d'entretiens, les équipes ont indiqué que l'apport des mentors / formateurs était inestimable et que leurs fonctions étaient multiples : contribuer à limiter le PA à la portée établie et à respecter les échéances fixées ; faciliter l'établissement de liens avec les principales parties prenantes ; et présenter de nouvelles idées, perspectives et ressources. Les formateurs et les mentors ont déclaré (au moyen d'un questionnaire) que leur rôle aurait pu être renforcé par leur participation plus précoce au projet collaboratif d'AQ, soit dès son établissement. Effectivement, la FCASS a travaillé avec les équipes à l'occasion du premier atelier, et immédiatement après celui-ci, à l'identification du type d'expertise thématique qui leur serait la plus utile pour ensuite inviter des formateurs 
et des mentors à participer au projet. Malgré cela, $80 \%$ des formateurs / mentors estimaient avoir réussi à établir un lien de confiance avec leurs équipes. En termes de clarté, 78 \% des formateurs / mentors ont déclaré que leur rôle était clair ; toutefois, certains ont rapporté un certain degré d'ambiguïté au sujet de la manière de traiter des questions délicates, comme les moyens d'appuyer une équipe qui vit des bouleversements (p. ex., les cas de roulement d'un membre de l'équipe ou d'une charge de travail liée au PA menacée par un "glissement de sa portée »).

Sur le plan de l'application de la plateforme d'apprentissage en ligne, personnalisée et bilingue, (surnommée « le Bureau virtuel de l'Atlantique "), les conclusions des sondages montrent qu'elle a davantage pris la forme d'une plate-forme de gestion des connaissances (pour l'entreposage de documents) ; ses autres fonctions étant limitées. En fait, un formateur remarquait que « le portail virtuel avait été utile pour [lui] en tant que formateur, mais probablement pas [utile aux équipes] ». Les données d'utilisation corroborent ce constat, indiquant de modestes pointes d'ouvertures de session et de pages consultées pré- et post-ateliers ; l'application de la plateforme étant faible autrement.

Les participants ont fait des observations positives quant à la disponibilité du personnel de la FCASS ; à la prestation bilingue du programme; et à la nature itérative et souple du programme d'apprentissage. « Je ne me rappelle pas un seul moment où nous ayons demandé du soutien sans le recevoir ", déclarait un participant, " [la FCASS décelait des besoins] dont nous ignorions l'existence et nous aidait à les combler chemin faisant. » Un autre participant indiquait que « tout était bien planifié, de la structure générale jusqu'aux détails et à l'organisation. On avait l'impression que tout fonctionnait comme sur des roulettes. » D'autres caractéristiques importantes de la
FCASS relevées par les participants comprenaient son expertise et sa compréhension du paysage sanitaire du Canada; sa philosophie qui consiste à ne « jamais abandonner les derniers lambins ", mais plutôt de consacrer du temps et de l'énergie à l'appui de chaque équipe ; sa capacité de recruter des enseignants experts, des formateurs et des mentors ; et son dévouement à une approche régionale, comprenant un membre du personnel dans la région (la liaison régionale).

\section{Promouvoir la pérennité des systèmes de santé}

En ce qui concerne la pérennité du système de santé, il n'est possible que de formuler des observations à ce stade, étant donné que la plupart des équipes de la COSA n'ont pas encore mis en œuvre leur projet et que d'autres n'en sont qu'aux premières étapes de la mise en œuvre de leur initiative. Encore moins de constats peuvent être formulé sur la question de l'efficacité et de la réduction du coût des soins par habitant, bien que ces questions de pérennité soient indispensables. Phillips et ses collègues (2013) font davantage référence à la question de la " comptabilisation des coûts " dans le commentaire qui suit, dans lequel ils décrivent les mesures de soutien apportées aux équipes sur le plan de la comptabilisation des coûts d'amélioration, ainsi que les méthodes employées par la FCASS, le cas échéant, afin d'aider les équipes à cerner les coûts-avantages de nouvelles approches de prestation de soins. Bien que plusieurs PA de cette Collaboration avaient pour but de dispenser des soins de manière plus efficace (associés à des objectifs explicitement liés à l'efficacité ou la pertinence des soins comme la réduction du gaspillage et des double emplois dans le domaine des soins spécialisés pour les patients atteints de maladies chroniques multiples, la réduction des consultations aux urgences et des hospitalisations évitables grâce à l'amélioration des soins 
de santé communautaires et la sensibilisation des prestataires et des patients au SAG pour permettre une plus grande auto-efficacité en matière de PGMC), aucune des équipes n'a signalé de changement « avant et après » du point de vue des coûts unitaires, par exemple. En termes de pérennité des PA et des efforts des équipes en matière de remaniement des soins, étant donné l'évolution variable des projets (notamment quant au stade de leur mise en œuvre), il est difficile d'évaluer la pérennité. Toutefois, nous proposons plusieurs observations à cette fin :

- L' "évaluation du degré de préparation à l'amélioration » peut contribuer à définir des attentes réalistes. Elle peut, par ailleurs, contribuer à produire un impact plus important aux niveaux de l'équipe du PA et de la Collaboration si des mesures plus rigoureuses et une analyse axée sur la résolution de problèmes sont établies d'emblée (au-delà de ce que les « Critères de préparation " de la COSA ont été en mesure de réaliser) pour évaluer l'adéquation entre l'équipe et le PA et renforcer la capacité d'AQ. Cette mesure pourrait également contribuer à l'évaluation du niveau de risque associé à la capacité d'exécuter le projet et à y consacrer le temps nécessaire. Il peut également s'avérer avantageux de retenir les services de formateurs et de mentors dès le début du projet collaboratif afin de faciliter ce genre d'évaluation rigoureuse.

- Le temps et le dévouement sont essentiels à l'amélioration des soins. Bien qu'il s'agissait d'un projet collaboratif d'une durée de deux ans, ce qui, selon la littérature scientifique, est une durée supérieure à la moyenne (Nadeem et al. 2013), l'expérience du projet collaboratif d'AQ COSA confirme qu'apporter un changement pérenne à la conception, à la prestation et à l'évaluation des soins prend beaucoup de temps et de dévouement, souvent au-delà de la durée du projet collaboratif lui-même. La FCASS continuera d'assurer le suivi auprès des équipes de la COSA afin de déterminer combien de temps prend l'amélioration. La diffusion des PA, entretemps, réunit deux dimensions : la diffusion à l'interne (à l'intérieur des murs de l'organisation d'accueil) et la diffusion externe (au-delà de ses murs). Peu importe la portée, l'amélioration n'est pas statique et exige des efforts et un soutien continus au fil du temps. Même une fois l'objectif d'amélioration initial atteint, un nouvel objectif est susceptible de surgir tandis que les équipes d'amélioration deviennent plus conscientes de l'existence et de la résolution des problèmes. Ce qui importe est l'engagement en faveur d'une culture de l'amélioration et la reconnaissance des éléments nécessaires (en termes d'efforts, de temps et de ressources) à sa concrétisation.

- Le soutien local importe. Les équipes qui peuvent aligner les efforts de leur PA sur les priorités stratégiques des administrations locales et de leur organisation d'attache sont susceptibles de recevoir un soutien continu plus fiable. Cela est important, dès le départ (p. ex., réalisation d'un PA en parallèle avec des initiatives déjà en cours afin de tirer parti de ressources et de formes de soutien existantes) et une fois le soutien ou les ressources externes épuisés (p. ex., la capacité de l'équipe de poursuivre ses efforts une fois les ressources et le soutien de la Collaboration terminés). L'élaboration d'une communauté de pratique régionale peut fournir un appui supplémentaire aux équipes à l'échelle locale et contribuer à leur persévérance. On peut soutenir que l'approche faible en règles, qui est à la base de la création 
des PA des équipes, est sans doute un investissement dans leur pérennité locale (diffusion à l'interne), mais pas forcément dans leur diffusion externe. Une approche faible en règles laisse beaucoup de place à l'interprétation locale. D'une part, une telle approche permet une variation régionale et une personnalisation de la conception du PA de sorte que celui-ci soit adapté aux priorités et aux besoins locaux. D'autre part, cette approche comporte le risque inhérent que les régions s'engagent dans des PA très différents les uns des autres, ce qui pourrait limiter leur diffusion interrégionale future et contribuer à l'incapacité des équipes à créer des $\mathrm{PA}$ interrégionaux et interprovinciaux dont le potentiel d'impact systémique est beaucoup plus grand.

\section{Perspectives d'avenir}

La modernisation de la façon dont les soins de santé réagissent aux besoins d'une population de plus en plus aux prises avec des maladies chroniques est un des plus grands défis que le système de soins de santé actuel doit relever. Plus de gens vivent avec de multiples affections chroniques, ce qui crée de la pression sur les systèmes de soins de santé qui s'appuient principalement sur des soins hospitaliers conçus pour traiter des maladies aiguës pendant de brèves périodes de temps. Ce document présente un examen approfondi de la COSA en tant que projet collaboratif d'AQ pan-canadien qui a développé un réseau de prestataires de soins de santé vivement intéressés à amorcer des améliorations en PGMC pour les patients et leurs familles. En définitive, à quoi est-on raisonnablement en droit de s'attendre de ce type d'initiative ? Le projet collaboratif d'AQ COSA a créé une prédisposition culturelle à l'appui de l'amélioration des soins de santé pour les patients atteints d'une maladie chronique et leurs familles. Cette expérience montre qu'il est possible, dans le contexte des soins de santé au Canada, de stimuler un véritable engagement à améliorer les soins aux patients atteints de maladies chroniques et à s'attaquer systématiquement à certains des problèmes et des obstacles associés à l'amélioration des soins de santé.

\section{Remerciements}

Nous souhaitons attirer l'attention sur la contribution de nos collègues qui ont conjointement conçu et entrepris l'évaluation de la COSA : Kaye Phillips (responsable principale), Claudia Amar (responsable du projet), Pernelle Smits (experte-conseil), Keesa Elicksen-Jensen, Tom Valente (expert-conseil) et Nurdin Akunov. Par ailleurs, nous saluons ceux qui ont rendu la COSA possible, avec des remerciements particuliers pour Meghan Rossiter (liaison régionale), Erin Leith (responsable de l'encadrement) et Christine (Kirby) Kirvan. En plus de recevoir un soutien financier de la part de la FCASS, la COSA a également obtenu une aide financière de la part de cinq ASR du Canada Atlantique : Nova Scotia Health Authority (anciennement Capital Health, N.-É.), Eastern Health ((T.-N.-L.), Health PEI, Réseau de santé Horizon et Réseau de santé Vitalité (N.-B.). La Fondation pour la santé Medavie a également parrainé chacun des quatre ateliers, tandis que la Health Association Nova Scotia a fourni un soutien en nature. Enfin et surtout, nous tenons à remercier l'énorme réseau de cadres supérieurs, d'enseignants, de formateurs et de mentors, ainsi que les équipes de professionnels de la santé dévoués qui ont participé à la COSA. La FCASS est financée au moyen d'une entente avec Santé Canada. Les opinions exprimées dans ce document ne représentent pas forcément celles du gouvernement du Canada.

\section{Références}

Les références peuvent être trouvés à l'adresse: http://www.longwoods.com/content/24503 